\title{
IDENTIFICATION OF RECALCITRANT STICKIES AND THEIR SOURCES IN NEWSPRINT PRODUCTION
}

\author{
Ruben Miranda ${ }^{1}$, Ana Balea ${ }^{2}$, Emilia Sanchez de la Blanca ${ }^{3}$, Isabel Carrillo ${ }^{4}$ and \\ Angeles Blanco ${ }^{1}$ \\ ${ }^{1}$ Department of Chemical Engineering, Faculty of Chemical Sciences, Complutense \\ University of Madrid - Avda. Complutense s/n 28040 Madrid (Spain) \\ ${ }^{2}$ Holmen Paper Madrid - C/ del Papel, 128947 Fuenlabrada, Madrid (Spain) \\ ${ }^{3}$ Department of Physical Chemistry I, Faculty of Chemical Sciences, Complutense \\ University of Madrid - Avda. Complutense s/n 28040 Madrid (Spain) \\ ${ }^{4}$ University School of Technical Industrial Engineering, Polytechnique University of \\ Madrid - Ronda de Valencia, 328012 Madrid (Spain)
}

\begin{abstract}
Deposits from different sections of a newsprint paper mill, using 100\% recovered paper, were analyzed following an analytical procedure based on SEM-EDX and consecutive solvent extraction steps with FTIR analyses of the different fractions. Polyvinyl acetate, polyacrylates, styrene butadiene rubber and derivatives of fatty acids/resin acids are the main stickies-related components identified in the deposits. The removal efficiency of these contaminants along the deinking line was studied by determining the composition of the dichloromethane extractives in the pulp by FTIR analyses. Although the total stickies content is reduced considerably during the process, some compounds, which are found in the deposits, are not removed selectively in the process, indicating their recalcitrant nature. FTIR analyses of unusable materials coming with the raw material (mainly board and mixed office waste), have demonstrated these materials are one of the main sources of these type of recalcitrant stickies.
\end{abstract}

Keywords: stickies, paper recycling, deposits, FTIR, dichloromethane extractives, deinking, unusable materials

\section{INTRODUCTION}

The recovery and utilization of recovered paper has increased over the past decades over the whole world, and this trend will continue. In Europe, after the success of the first European Declaration on Paper Recycling (2000-2005), a new voluntary commitment of the paper recycling chain has been signed with the challenge of achieving a recycling rate of $66 \%$ in $2010^{1}$. To achieve this objective, it is necessary to extend the current limits of paper recycling, especially in terms of availability and quality of the recovered paper. However, an extended recovered paper collection is always detrimental to its quality ${ }^{2-4}$, e.g. 
the increase in the collection from private households, to satisfy the paper industry needs, or the extended use of commingled instead of source-separated collection systems, yield recovered paper of a considerable low quality ${ }^{5-6}$. Besides, the cost pressure for segments of the recovered paper supply chain often counteracts any possible, and sometimes necessary, quality improvements ${ }^{7}$. Furthermore, quality demands for the finished paper are increasing with the rapid technological development of the publishing and converting industries. In summary, paper quality demands are increasing while the raw material quality is decreasing.

In this scenario, contaminants removal from the recovered paper is the key to increase the utilization rate, due to its direct influence on both process efficiency and product quality. Among these contaminants, stickies are the most detrimental in recovered paper recycling ${ }^{8-}$ 10. Stickies affect both the process efficiency because of the formation of deposits, the production of breaks or the reduction of the dry section efficiency due to felt clogging; and the quality of the final product because of the presence of spots, holes, and other defects ${ }^{11-}$ ${ }^{13}$. For this reason, it is important to identify the most problematic stickies and their sources to minimize them.

Potential contaminants in mills using recovered paper consist of a very broad range of chemical components, including high and low molecular weight organic compounds, natural and synthetic polymers, as well as inorganic chemicals. Stickies are not generally derived from a single contaminant source but from a combination of them ${ }^{14-15}$, e.g. adhesives, coating binders, ink residues, deinking chemicals and wood derivatives.

Adhesives are generally considered to be the most detrimental source for the formation of stickies deposits ${ }^{16-17}$. Most products made of paper and paperboard are put together with the help of adhesives to form complex finished products. In fact, paper and packaging adhesives have a dominant share of the adhesives market ${ }^{18}$. The most important polymers used for adhesives are ${ }^{19}$ : polyvinyl acetate (PVAc), polyacrylates, styrene butadiene rubber (SBR), ethylene vinyl acetate (EVA), styrene acrylate, butyl rubber, polyisobutene, styrene butadiene styrene (SBS), polyvinyl ether, polyethylene (PE), polyamide, polyurethane (PUR), polyisoprene (PIP), polyvinyl alcohol $\left(\mathrm{PVA}_{\mathrm{OH}}\right)$, etc. But also modified resins, unmodified resins, and synthetic resins can provide the necessary tackiness. The design of recycling compatible adhesives is currently of growing interest, since they can be removed early in the process, ideally using existing equipment and process design ${ }^{20-23}$.

Coating binders are used for the production of coated papers, one of the most predominant compounds (used in $80 \%$ of binders) is SBR latex ${ }^{24}$; PVAc and polyvinyl acrylate are also typically used ${ }^{25}$. As tacky impurities from printing inks, one must especially consider toner for copiers and laser printers since they "melt" onto the substrate paper during the printing process by heat and pressure and become fixed. Toners using SBR and polyvinyl acrylate 
contain the same chemical components as adhesives ${ }^{15}$. Deinking chemicals, e.g. collectors used in the flotation deinking process (soaps or saponified fatty acid) can also be a source of stickies as they are transferred to the paper machine (carryover) ${ }^{26-27}$. Wood extractives, rosins and wet strength additives are another possible cause of stickies deposits.

The complex nature of stickies deposits made their characterization and interpretation of the chemical analysis very difficult for a correct determination of the origin of the problems $^{28-29}$. Usually, almost all papermaking components are found in the deposits. Determination usually requires complex multi-step procedures with the application of several powerful analytical techniques ${ }^{14,28,30}$, e.g. Fourier-transform infrared spectroscopy (FTIR), pyrolysis gas chromatography (Py-GC), gel permeation chromatography (GPC), thermogravimetry, differential scanning calorimetric analysis (DSC), scaning electron microscopy-electron dispersive X-ray (SEM-EDX), X-ray fluorescence (XRF) and nuclear magnetic resonance (NMR). The combination of FTIR with multi-step solvent extractions is the most commonly used ${ }^{15-16}$, normally accompanied by inorganic specific analytical techniques such as EDX or XRF. Solvents used differ slightly between authors but ethanol, acetone, trichloromethane, ethyl acetate, trichloroethylene or tetrahydrofuran (THF) are commonly used $^{14,28,31}$.

Although several stickies quantification methods for the pulps have been proposed by different authors ${ }^{12,32-37}$, the establishment of a universal method is still not completed ${ }^{27,38,39}$, making difficult to study the evolution of the stickies content along the process and the removal efficiency of the different stages. Solvent extraction with dichloromethane, trichloromethane, dimethylformamide, THF or methyl tertiary butyl ether has been used extensively in the literature ${ }^{14,35,40-42}$. Dichloromethane has demonstrated to be more selective to stickies than other solvents, which obtain higher yields but extract other nonsticky components as lignin components, e.g. dimethylformamide ${ }^{35}$. Dichloromethane has demonstrated to be a good indicator for the contaminants contained in the pulp $p^{41,43-44}$ and paper machine deposits contain large amounts of dichloromethane extractible materials, between 20 and $50 \%{ }^{41,43}$.

Despite industry's best efforts to eliminate stickies, only macrostickies $(>100 \mu \mathrm{m})$ can be removed effectively in the process, even up to $99 \%$ in modern mills with $0.1 \mathrm{~mm}$ fine screening ${ }^{45}$. However, microstickies $(<100 \mu \mathrm{m})$ are still a problem, they represent the main origin of the deposit potential, $70-90 \%$ of the current total stickies content are microstickies $^{31,41,43,46}$ and, as they are not removed effectively in the process, they remain as recalcitrant in the process ${ }^{28,47}$. The identification of the origin of these stickies, especially those considered as the most problematic, is the key for achieving a good quality control of the recovered paper and a reduction in the number of disturbances caused to the process. Although recovered paper may be used for producing very different products, specific 
requirements have to be met with regards to the manufacture of graphic paper, as in the case of newsprint paper production. Very limited references are available for the determination of the exact origin of the stickies in the raw material coming to the mill ${ }^{48-50}$, especially in the case of the production of graphic papers, where only the studies of N.N.-C. Hsu et al. ${ }^{51}$, focused on mixed office waste (MOW), and M. Vundamina ${ }^{52}$, focused on mixed household, have been carried out.

This study presents the results of the analyses of a variety of stickies deposits collected at various locations in a newsprint paper mill using 100\% recovered paper (Holmen Paper Madrid) in order to characterize what are the most detrimental components related to stickies deposition. In addition, FTIR analyses of the dichloromethane extract of pulp samples taken along the deinking line were used to establish the removal efficiency of the recalcitrant stickies in the different processes and their possible origin. Finally, the analysis of the furnish has allowed us to identify the main contaminant sources.

\section{METHODOLOGY}

\section{Analysis of deposits and pulp samples}

Once a deposit is detected in the process, it is collected and handled with latex gloves and stored in a sealed plastic bag. The bag is then sent to the laboratory for investigation together with a data sheet in which the fundamental information of the sample is included, e.g. hour, date, location, the deposit's physical characteristics, and the most relevant production parameters such as paper machine speed, chemicals' dosages, etc. These data are transferred to a database for the creation of a library in order to predict the origin of future problems from the analysis of the origin of the analyzed deposits.

Figure 1 shows the procedure followed for the analysis of the deposits. First, deposits were analyzed by SEM, to analyze the morphology of the original deposit, by sputter-coating with a thin carbon layer of the deposit. The presence of elements was detected by EDX. Scanning electron micrographs were obtained on a JEOL model JSM 6400 electron microscope with an Oxford EDX microanalysis at $20 \mathrm{kV}$ and varying levels of magnification. Deposits were also directly analyzed by FTIR after the formation of pellets with $\mathrm{KBr}$, following the procedure of J.D. Holbery et al. ${ }^{28}$. In this procedure, pellets are made by mixing $3 \mathrm{mg}$ of the extract with $200 \mathrm{mg} \mathrm{KBr}$ (Scharlau Chemie, FTIR grade, stored in desiccate at least $24 \mathrm{~h}$ prior to test). After a thorough mixing of the extract and $\mathrm{KBr}$, the mixture is dried and the pellet is produced by placing the material in a stainless steel die and pressing using a manual press. A Nicolet-Magna 750 spectrometer was used for recording the spectra at $4 \mathrm{~cm}^{-1}$ resolution, four scans were taken for both the background and the sample. 
A multi-step solvent extraction of the deposit followed by FTIR analysis was also carried out for the identification of the main components of the deposits. Hot ethanol is the first solvent used since most resin compounds of wood, hydrocarbon oils and polyvinyl acetates have a good solubility in it ${ }^{15,28}$. The components that are insoluble in ethanol undergo an additional extraction with ethyl acetate since a wide range of the synthetic polymers possibly present in deposits can dissolve in this solvent ${ }^{15}$. In some cases, ethanol residue can also be extracted with trichloromethane for a better identification of the origin of some bands of the spectra. Materials that are not extracted after this multi-step solvent extraction methodology only include fibers, starch and inorganics ${ }^{28}$. The extraction is performed by direct reflux of the solvent. After the extraction, the solvent was removed by using a rotary evaporator and FTIR spectra were recorded in a Nicolet-Magna 750 with a Spectratech IRPlan Advantage Microscope. The resolution and the number of scans collected were varied to obtained spectra with a good signal-to-noise ratio.

The total content of stickies in pulp samples was measured at the most representative points ( 9 sample points) of the deinking line of the mill as has been reported previously by $\mathrm{R}$. Miranda et al. ${ }^{44}$. Two different surveys were carried out: one at a regular level of stickies and one at a high level of stickies. After that, extractives were analyzed by FTIR with pellets of $\mathrm{KBr}$ as was already described. A Mattson Satellite 5000 FTIR was used to record the spectra of the pellet. Spectra were recorded at a $4 \mathrm{~cm}^{-1}$ resolution and 4 scans were taken for both the background and the sample.

\section{Identification of recalcitrant stickies in the unusable material fraction of the furnish}

Fourteen samples of unusable material for the production of newsprint (including boards and some materials considered as MOW) were collected from the furnish of the mill. These samples have been collected as being representative of the very different unusable materials coming into the mill. Selected pieces of these samples were cut in order to obtain the fractions in which the presence of adhesives was most evident and have been analyzed by FTIR in order to determine the presence of the most important recalcitrant stickies detected in the stickies deposits collected at the same mill such as PVAc, polyacrylates, EVA and SBR. Analyses have been carried out using a Perkin Elmer Spectrum GX spectrophotometer with an Attenuated Total Reflectance (ATR) attachment.

\section{RESULTS AND DISCUSSION}

During four months of operation, a total of 16 deposits have been collected at the mill. In addition, another 13 deposits were collected during cleaning stops of the production line. These deposits have normally appeared in the final product (i.e. specks on paper) or on the 
machinery (i.e. felts and rolls in the paper machine or in the deinking process). The deposits were mostly found on the wire section, the press section and the drying section of the paper machine, as it was also observed by M. Douek et al. ${ }^{11}$ in a survey among 9 newsprint mills in Canada and North America, with recycled contents from 5 to $80 \%$.

Tables 1 and 2 summarizes the list of deposit samples, collected at regular operation of the mill and in cleaning stops, respectively, describing their appearance, the location where they were collected, and their chemical composition. Figure 2 shows a scheme of the paper machine showing where samples were collected.

Table 1.- Main characteristics and composition of the mill deposits collected during regular operation.

\begin{tabular}{|c|c|c|c|c|}
\hline Ref. & Appearance & Location & Organic constituents & Inorganic constituents \\
\hline 1 & $\begin{array}{l}\text { Black plastic-like } \\
\text { pieces }\end{array}$ & Screw press & $\begin{array}{l}\text { Fatty acid salts and styrene } \\
\text { copolymers }\end{array}$ & $\begin{array}{l}\text { Kaolin, silicates, } \mathrm{Mg}, \mathrm{Na} \text {, and traces } \\
\text { of } \mathrm{Cl}, \mathrm{Fe}, \mathrm{K}, \mathrm{S} \text { and } \mathrm{Al}\end{array}$ \\
\hline 2 & $\begin{array}{l}\text { Black speck on } \\
\text { paper }\end{array}$ & Winder & $\begin{array}{l}\text { Acrylic polymers, polyvinyl } \\
\text { acetate and fatty acids }\end{array}$ & $\begin{array}{l}\text { Calcium carbonate, kaolin, } \mathrm{Al} \text {, and } \\
\text { traces of } \mathrm{K}, \mathrm{S} \text { and } \mathrm{Fe}\end{array}$ \\
\hline 3 & $\begin{array}{l}\text { Paper agglomerate } \\
\text { (dirty of pulp) }\end{array}$ & Reel & Polyamides & $\begin{array}{l}\text { Calcium carbonate, } \mathrm{Si}, \mathrm{Al}, \mathrm{P}, \mathrm{K}, \mathrm{S} \text {, } \\
\text { and traces of } \mathrm{Mg} \text { and } \mathrm{Na}\end{array}$ \\
\hline 4 & $\begin{array}{l}\text { Speck of paper } \\
\text { (dirty of pulp) }\end{array}$ & Reel & & Ca, Si, Al, S \\
\hline 5 & $\begin{array}{l}\text { Pink paper } \\
\text { agglomerate }\end{array}$ & $\begin{array}{l}\text { Circuit of clear } \\
\text { water }\end{array}$ & $\begin{array}{l}\text { Salts of saturated fatty/resin } \\
\text { acids and traces of binders }\end{array}$ & Kaolin, $\mathrm{Ca}, \mathrm{Al}$, and traces of $\mathrm{Cl}$ and $\mathrm{S}$ \\
\hline 6 & $\begin{array}{l}\text { Hard greyish } \\
\text { crumbs }\end{array}$ & Wire section & Cellulose & $\begin{array}{l}\text { Calcium carbonate, sulphates, kaolin, } \\
\text { talc and low amounts of } \mathrm{Al}, \mathrm{Na} \text { and } \\
\mathrm{Mg}\end{array}$ \\
\hline 7 & $\begin{array}{l}\text { Black dust over } \\
\text { paper }\end{array}$ & Calender & Polyvinyl acetate & $\begin{array}{l}\text { Calcium carbonate, silicate, } \mathrm{Al} \text { and } \\
\text { traces of } \mathrm{Mg}, \mathrm{K}, \mathrm{S} \text { and } \mathrm{Fe}\end{array}$ \\
\hline 8 & Specks on paper & Wire section & Cellulose & $\begin{array}{l}\text { Calcium carbonate, calcium sulphate, } \\
\text { silicate and } \mathrm{Al}\end{array}$ \\
\hline 9 & $\begin{array}{l}\text { Black speck on } \\
\text { paper }\end{array}$ & Calender & Acrylates and resin & $\begin{array}{l}\text { Calcium carbonate, kaolin, } \mathrm{Al} \text {, low } \\
\text { amount of } \mathrm{S} \text { and traces of } \mathrm{Fe}\end{array}$ \\
\hline 10 & Specks on paper & Press battery & $\begin{array}{l}\text { Esters of fatty acids, polyvinyl } \\
\text { acetate and acrylic polymers }\end{array}$ & $\begin{array}{l}\text { Talc, calcium carbonate, } \mathrm{Al}, \mathrm{Fe} \text { and } \\
\text { low amounts of } \mathrm{S}, \mathrm{Na}, \mathrm{K} \text { and } \mathrm{Cl}\end{array}$ \\
\hline 11 & Specks on paper & Reel & & $\begin{array}{l}\text { Calcium carbonate, silicate, } \mathrm{Al} \text { and } \\
\text { low amounts of } \mathrm{S}\end{array}$ \\
\hline 12 & $\begin{array}{l}\text { Transparent specks } \\
\text { on paper }\end{array}$ & $\begin{array}{l}\text { Wire section: } \\
\text { suction boxes }\end{array}$ & Esters of fatty acids & $\begin{array}{l}\text { Calcium carbonate, kaolin, sulphates, } \\
\mathrm{Al} \text { and } \mathrm{K}\end{array}$ \\
\hline 13 & $\begin{array}{l}\text { Black paper } \\
\text { agglomerates }\end{array}$ & $\begin{array}{l}\text { Coarse } \\
\text { screening }\end{array}$ & $\begin{array}{l}\text { Fatty acid salts and styrene } \\
\text { copolymers }\end{array}$ & $\begin{array}{l}\text { Calcium carbonate, kaolin, } \mathrm{Al}, \mathrm{Mg} \text {, } \\
\mathrm{Na} \text {, and traces of } \mathrm{S}\end{array}$ \\
\hline 14 & $\begin{array}{l}\text { Transparent specks } \\
\text { on paper }\end{array}$ & Reel & Esters of fatty acids & Calcium carbonate, $\mathrm{Si}$ and $\mathrm{Al}$ \\
\hline 15 & Fiber agglomerate & $\begin{array}{l}\text { Collect pit of } \\
\text { headbox }\end{array}$ & $\begin{array}{l}\text { Salts of saturated fatty/resin } \\
\text { acids }\end{array}$ & $\begin{array}{l}\text { Kaolin, sulphates, } \mathrm{Ca}, \mathrm{Na} \text {, and low } \\
\text { amounts of } \mathrm{Al}, \mathrm{K} \text { and } \mathrm{Si}\end{array}$ \\
\hline 16 & $\begin{array}{l}\text { Black speck on } \\
\text { paper }\end{array}$ & Winder & $\begin{array}{l}\text { Acrylic polymers, polyvinyl } \\
\text { acetate and fatty acids }\end{array}$ & $\begin{array}{l}\text { Calcium carbonate, kaolin, } \mathrm{Al} \text { and } \\
\text { traces of } \mathrm{S} \text { and } \mathrm{Fe}\end{array}$ \\
\hline
\end{tabular}


Table 2.- Main characteristics and composition of the mill deposits collected during cleaning stops.

\begin{tabular}{|c|c|c|c|c|}
\hline Ref. & Appearance & Location & Organic constituents & Inorganic constituents \\
\hline 17 & $\begin{array}{l}\text { Brownish, hard } \\
\text { crumbs }\end{array}$ & $\begin{array}{l}\text { Under the foils } \\
\text { of wire section }\end{array}$ & Esters of fatty acids & $\begin{array}{l}\text { Calcium carbonate, kaolin, } \mathrm{Al} \text {, and } \\
\text { traces of } \mathrm{P}, \mathrm{S} \text { and } \mathrm{Mg}\end{array}$ \\
\hline 18 & $\begin{array}{l}\text { Brownish sandy } \\
\text { material }\end{array}$ & $\begin{array}{l}\text { Cleaners of the } \\
\text { paper machine }\end{array}$ & $\begin{array}{l}\text { Polyvinil acetate and fatty acid } \\
\text { salts }\end{array}$ & $\begin{array}{l}\text { Silicates, calcium carbonate, } \mathrm{Al}, \mathrm{Na}, \mathrm{K} \\
\text { and traces of } \mathrm{S} \text { and } \mathrm{Fe}\end{array}$ \\
\hline 19 & Brownish crumbs & Roller press & Esters of fatty acids & $\begin{array}{l}\text { Calcium carbonate, sulphates, } \\
\text { silicates, talc, } \mathrm{Al}, \mathrm{Ca}, \mathrm{Na} \text { and } \mathrm{Mg}\end{array}$ \\
\hline 20 & $\begin{array}{l}\text { Brown wrinkled } \\
\text { paper }\end{array}$ & Press & $\begin{array}{l}\text { Low amount of fatty acids and } \\
\text { stickies }\end{array}$ & $\begin{array}{l}\text { Kaolin, } \mathrm{Al} \text { and low amounts of } \mathrm{Cl}, \mathrm{K} \\
\text { and } \mathrm{Fe}\end{array}$ \\
\hline 21 & $\begin{array}{l}\text { White deposit over } \\
\text { felt }\end{array}$ & Press & Esters of fatty/resin acids & $\begin{array}{l}\text { Calcium carbonate, kaolin, } \mathrm{Al} \text { and low } \\
\text { amounts of S }\end{array}$ \\
\hline 22 & $\begin{array}{l}\text { White deposit over } \\
\text { textile material }\end{array}$ & Wire section & Esters of fatty/resin acids & $\begin{array}{l}\text { Calcium carbonate, kaolin, Al and low } \\
\text { amounts of S }\end{array}$ \\
\hline 23 & $\begin{array}{l}\text { Brown sand fixed } \\
\text { to textile }\end{array}$ & $\begin{array}{l}\text { Wire of disk } \\
\text { filter } \\
\text { (deinking) }\end{array}$ & Esters of fatty/resin acids & Calcium carbonate and $\mathrm{Si}$ \\
\hline 24 & $\begin{array}{l}\text { Brownish sandy } \\
\text { material }\end{array}$ & $\begin{array}{l}\text { Cleaners of the } \\
\text { paper machine }\end{array}$ & & $\begin{array}{l}\text { Silicates, Al, Fe, K, Na, S and low } \\
\text { amounts of calcium carbonate }\end{array}$ \\
\hline 25 & $\begin{array}{l}\text { Brown wrinkled } \\
\text { paper }\end{array}$ & $\begin{array}{l}\text { Suction roller } \\
\text { of wire section }\end{array}$ & Esters of fatty/resin acids & $\begin{array}{l}\text { Calcium carbonate, kaolin, silicate, } \\
\text { sulphate, } \mathrm{Al} \text { and traces of Fe }\end{array}$ \\
\hline 26 & $\begin{array}{l}\text { Hard white crumbs } \\
\text { with brown } \\
\text { borders }\end{array}$ & $\begin{array}{l}\text { In the foils of } \\
\text { the wire } \\
\text { section }\end{array}$ & $\begin{array}{l}\text { Esters of fatty acids and } \\
\text { styrene copolymers }\end{array}$ & $\begin{array}{l}\text { Calcium carbonate, kaolin, silicate, } \\
\mathrm{Al}, \mathrm{S} \text {, and traces of } \mathrm{Zn}\end{array}$ \\
\hline 27 & $\begin{array}{l}\text { Black plastic-like } \\
\text { deposit over paper }\end{array}$ & Ink roller & $\begin{array}{l}\text { Styrene copolymers and } \\
\text { acrylates }\end{array}$ & $\begin{array}{l}\text { Calcium carbonate, kaolin, } \mathrm{Al}, \mathrm{S} \text { and } \\
\mathrm{Fe}\end{array}$ \\
\hline 28 & $\begin{array}{l}\text { Brownish sandy } \\
\text { material }\end{array}$ & $\begin{array}{l}\text { Cleaners } \\
\text { depuration }\end{array}$ & . & Silicates, Al, Fe, K, Na and $\mathrm{Ca}$ \\
\hline 29 & $\begin{array}{l}\text { Hard white crumbs } \\
\text { with brown } \\
\text { borders }\end{array}$ & $\begin{array}{l}\text { At the end of } \\
\text { foils under } \\
\text { wire section }\end{array}$ & Esters of fatty/resin acids & $\begin{array}{l}\text { Calcium carbonate, kaolin, } \mathrm{Na}, \mathrm{Al}, \mathrm{S} \\
\text { and } \mathrm{Fe}\end{array}$ \\
\hline
\end{tabular}

Six of the 29 analyzed deposits contain only inorganic constituents without any organic substance, representing $21 \%$ of the samples. The origin of these deposits is the scale of salts as calcium carbonate or calcium sulphate (mainly coming from the raw material's fillers but influenced by the addition of, for example, sulphuric acid for $\mathrm{pH}$ control in the process), or the scale of silicates (mainly coming from the addition of sodium silicate in the pulping stage $)^{53-55}$.

The other 23 samples ( $79 \%$ of the analyzed deposits) present both organic and inorganic constituents. Inorganic materials detected in the deposits can be identified as fillers or pigments, mainly calcium carbonate and kaolin, commonly used in the manufacturing of the old newsprints and old magazines used as raw material in the mill; calcium sulphate may also be present. These materials are not naturally tacky, they are not the active 
components in the formation of deposits although can enhance deposition of other components $^{56}$.

The most common organic compounds in these deposits (in 20 of the 23 deposits) are fatty acids and their esters or resin acids. These compounds can be introduced to the system as deinking chemicals (soap or saponified fatty acids). Although these collectors are largely removed with the flotation foam and the deinking loop is separated, a carryover of calcium soaps into the paper machine loop may take place ${ }^{14,15,27}$. Other possible origins of these compounds are some resins and fatty acids used in the formulation of adhesives or wet strength resins and the wood extractives associated with the cellulose fibers. Although high removal efficiency during the stock preparation processes is possible (especially for free fatty acids), other compounds are not removed efficiently (e.g. resin acids or esterified fatty acids $^{26}$. The importance of these compounds in the deposits is highly variable. Johansson et al. ${ }^{41}$ have found that these compounds can be as high as $40-45 \%$ of the dichloromethane extractable material from the deposits of two testliner mills, while T. Sarja et al. ${ }^{31}$ found that these compounds were a negligible contributor to the drying section deposition in a newsprint mill. These compounds are usually named as "wood extractives and their derivatives" although the main origin of these compounds is in the deinking chemicals, not in the wood extractives itself, when using $100 \%$ recovered paper as raw material. They usually play an active role in the deposition, alone or by agglomeration with the stickies, e.g. by melting in the drying section ${ }^{57}$.

PVAc, polyacrylates and some styrene compounds have also been identified as predominant stickies related substances detected in the deposits. PVAc and polyacrylates were detected in six samples and styrene copolymers in five. The origin of these components is mainly in the formulation of converting adhesives but they are also used as papermaking or coating additives. These results are in agreement with X. Wang et al. ${ }^{58}$, who also observed that the primary constituents of stickies collected in the drying section of a papermachine, also producing newsprint but using recovered paper and mechanical wood pulp as raw material, were PVAc, polyacrylates and SBR. M. Douek et al. ${ }^{56}$ also found substances such as PVAc, EVA and SBR, in the deposits of the drying section of newsprint paper machines, with different recycled contents. Similar results have been also obtained in the stickies analyses in the production of container board and linerboard from old corrugated containers $(\mathrm{OCC})^{28}$. In one of the deposits analyzed (no. 3), the presence of polyamides has also been detected, probably coming from one of the chemicals used in the process such as flocculant, a polyacrylamide. Table 3 summarizes the main analyses of deposits described in the literature. 
Table 3.- Results of analyses of deposits described in the literature.

\begin{tabular}{|c|c|c|c|}
\hline Origin of the deposits & $\begin{array}{l}\text { Methodology of } \\
\text { analysis }\end{array}$ & Constituents & Ref. \\
\hline \multicolumn{4}{|c|}{ NEWSPRINT PAPER } \\
\hline $\begin{array}{l}\text { Deposits from press } \\
\text { section of } 5 \text { newsprint } \\
\text { mills with different } \\
\text { recycled contents } \\
(0-100 \% \text { DIP })\end{array}$ & $\begin{array}{l}\text { Sequential solvent } \\
\text { extractions with } \\
\text { ethanol, acetone and } \\
\text { trichloromethane, } \\
\text { followed by FTIR and } \\
\text { PGC }\end{array}$ & $\begin{array}{l}\text { Average composition of the deposits: } 20 \% \text { wood } \\
\text { extractives and derivatives (wood resins and ink } \\
\text { residues); } 30 \% \text { inorganics (clay, talc, and titanium } \\
\text { dioxide); } 5-10 \% \text { hydrocarbon oils; } 20 \% \text { polymers } \\
\text { composed of low molecular weight extractable } \\
\text { materials (SBR-based copolymers, PVAc, } \mathrm{PVA}_{\mathrm{OH}} \\
\text { and in a lesser extent EVA and polyacrylates) and } \\
\text { non extractable polymer fractions (crosslinked } \\
\text { polymers and high-molecular-weight polyethylene) }\end{array}$ & (14) \\
\hline $\begin{array}{l}\text { Deposits collected in } \\
\text { different locations of } 11 \\
\text { mills producing newsprint } \\
\text { with different recycled } \\
\text { content }(3-100 \%)\end{array}$ & $\begin{array}{l}\text { Sequential solvent } \\
\text { extractions with } \\
\text { ethanol, acetone and } \\
\text { trichloromethane, } \\
\text { followed by FTIR. In } \\
\text { some cases, also } \\
\text { toluene is used }\end{array}$ & $\begin{array}{l}\text { Average composition of press section deposits for } \\
\text { high recycled content ( } 25-100 \%): 5.8 \% \text { wood } \\
\text { fibres; } 23 \% \text { wood extractives, hydrocarbon oil; } \\
41 \% \text { : inorganics; } 10 \% \text { extractable polymers; } 20 \% \\
\text { others (metal soaps, unextractable polymers and } \\
\text { other unidentified material). In the case of low } \\
\text { recycled content ( } 5-10 \%) \text {, the amount of extractable } \\
\text { polymers was negligible. }\end{array}$ & $(56)$ \\
\hline $\begin{array}{l}\text { Deposits collected in the } \\
\text { drying section of } 6 \\
\text { papermachines producing } \\
\text { newsprint or SC paper }\end{array}$ & $\begin{array}{l}\text { THF extraction and } \\
\text { pyrolysis-GC/MS, } \\
\text { HPLC-SEC or GC/MS }\end{array}$ & $\begin{array}{l}\text { Average composition of the deposits: } 0.5-5 \% \text { wood } \\
\text { extractives and derivatives; } 4-12 \% \text { acrylates; } 1-4 \% \\
\text { vinyl acetates; } 1-2 \% \text { styrene compounds. }\end{array}$ & (57) \\
\hline $\begin{array}{l}\text { Deposit collected in the } \\
\text { drying section of a mill } \\
\text { producing newsprint, MF } \\
\text { and SC from } 100 \% \\
\text { recovered paper }\end{array}$ & $\begin{array}{l}\text { THF extraction and } \\
\text { pyrolysis-GC/M, } \\
\text { HPLC-SEC or GC/MS }\end{array}$ & $\begin{array}{l}\text { Analysis of one deposit: } 0.40 \% \text { wood extractives; } \\
25 \% \text { inorganics (Ash, } 500{ }^{\circ} \mathrm{C} \text { ); } 6 \% \text { acrylates; } 1.5 \% \\
\text { vinyl acetates; } 1.2 \% \text { styrene compounds; } 26 \% \text { non- } \\
\text { extracted organics; } 38 \% \text { other organics extracted by } \\
\text { THF (not identified as stickies: wood extractives, } \\
\text { cellulose, lignin, starch or sizing agents); } 3.1 \% \text { re- } \\
\text { extract with dichloromethane. }\end{array}$ & $(31)$ \\
\hline $\begin{array}{l}\text { Deposits in a wire of the } \\
\text { deinking plant ( } 7 \\
\text { deposits) and in the wire } \\
\text { of the paper machine wire } \\
\text { (12 deposits) in a } \\
\text { newsprint mill with } 35 \% \\
\text { recycled content }\end{array}$ & $\begin{array}{l}\text { THF extraction, } \\
\text { fractionation by SEC } \\
\text { and FTIR analysis. } \\
\text { Polymers were also } \\
\text { analyzed by Py-GC } \\
\text { and low molecular size } \\
\text { fractions by GC }\end{array}$ & $\begin{array}{l}\text { Main components: wood extractives, EVA, acrylic } \\
\text { polymers and styrene compounds (styrene isoprene } \\
\text { styrene and SBS). }\end{array}$ & $(40)$ \\
\hline $\begin{array}{l}\text { Deposits collected in the } \\
\text { drying section of a mill } \\
\text { producing newsprint from } \\
\text { DIP and TMP }\end{array}$ & $\begin{array}{l}\text { FTIR and GC-MS } \\
\text { analysis }\end{array}$ & Main components: PVAc, polyacrylates and SBR. & $(58)$ \\
\hline
\end{tabular}




\begin{tabular}{|c|c|c|c|}
\hline $\begin{array}{l}\text { Deposits from } 4 \text { mills } \\
\text { using a recycled content } \\
\text { based on OCC from } 30 \text { to } \\
100 \% \text {. Most of the } \\
\text { deposits are from the } \\
\text { drying section }\end{array}$ & $\begin{array}{l}\text { Sequential solvent } \\
\text { extractions with } \\
\text { ethanol, acetone and } \\
\text { trichloromethane, } \\
\text { followed by FTIR. In } \\
\text { some cases, toluene is } \\
\text { also used }\end{array}$ & $\begin{array}{l}\text { Typical composition of a deposit: } 47 \% \text { wood fibre } \\
\text { and starch; } 8 \% \text { wood resin, hydrocarbons; } 21 \% \\
\text { inorganics; } 9.3 \% \text { PVAc and } \mathrm{PVA}_{\mathrm{OH}} ; 7.6 \% \text { EVA } \\
\text { and SBR; } 7.4 \% \text { carboxylated compounds. }\end{array}$ & (56) \\
\hline $\begin{array}{l}\text { Deposits collected in } \\
\text { different locations from } 3 \\
\text { mills producing container } \\
\text { board and linerboard using } \\
\text { OCC as their principal } \\
\text { furnish (up to } 100 \% \text { ) }\end{array}$ & $\begin{array}{l}\text { Sequential solvent } \\
\text { extractions with } \\
\text { ethanol and acetone, } \\
\text { followed by FTIR, } \\
\text { DSC,XRF and SEM } \\
\text { analyses }\end{array}$ & $\begin{array}{l}25-35 \% \text { fiber; } 12-15 \% \text { inorganics; } 30 \% \text { extractable } \\
\text { polymeric material (long-chain hydrocarbons, wood } \\
\text { resins, PVAc, PVA } \\
\text { molecular-weight } \mathrm{PE} \text { ); } 15 \% \text { non-extractable high- } \\
\text { molecular-weight PE or crosslinked polymers; } 2- \\
5 \% \text { starch residue. }\end{array}$ & (28) \\
\hline $\begin{array}{l}\text { Deposits collected from } \\
\text { center press doctor bar and } \\
\text { felt of the } 3 \text { papermachine } \\
\text { using OCC as raw material }\end{array}$ & FTIR, XRF and DSC & $\begin{array}{l}\text { The number of primary matches found in the FTIR } \\
\text { analyses of } 69 \text { deposits are: } 33.3 \% \text { carbon wax; } \\
29.0 \% \text { PE; } 23.1 \% \text { hot-melt formulations; } 7.2 \% \\
\text { PVA }_{\mathrm{OH}} \text {; } 4.3 \% \text { SBR; } 1.4 \% \text { acrylates; } 1.4 \% \text { calcium } \\
\text { carbonate. }\end{array}$ & $(59)$ \\
\hline $\begin{array}{l}\text { Deposits from the drying } \\
\text { section and the wire } \\
\text { section of two different } \\
\text { testliner mills }\end{array}$ & $\begin{array}{l}\text { DCM extraction and } \\
\text { FTIR analysis }\end{array}$ & $\begin{array}{l}\text { Average composition: } 20-40 \% \text { dichloromethane- } \\
\text { extractable material (PVAc, acrylates and } \\
\text { butadienes). Filler materials in high concentration. } \\
\text { A deposit collected in the drying section: } 10-15 \% \\
\text { wood extractives; } 40-45 \% \text { PVAc and EVA; }<5 \% \\
\text { polybutadine compounds; }<1 \% \text { polystyrene } \\
\text { compounds; }<1 \% \text { polyacrylates compounds; } 40- \\
45 \% \text { others. } \\
\text { A deposit collected in the wire section: } 40-45 \% \\
\text { wood extractives; } 15-20 \% \text { polyacrylates } \\
\text { compounds; } 10 \% \text { polybutadine compounds; } 10 \% \\
\text { polystyrene compounds. } 2 \% \text { PVAc and EVA; } 25 \% \\
\text { others. }\end{array}$ & (41) \\
\hline $\begin{array}{l}\text { Deposit in the guide rolls } \\
\text { and felts of the paper } \\
\text { machine in a board mill } \\
\text { using } 100 \% \text { recovered } \\
\text { paper }\end{array}$ & $\begin{array}{l}\text { FTIR of the original } \\
\text { and the ashed sample. } \\
\text { Next, THF extraction } \\
\text { and FTIR, GC and } \\
\text { GPC analyses of the } \\
\text { extracts }\end{array}$ & $\begin{array}{l}\text { Composition of a deposit: } 19 \% \text { inorganics (ash, } 550 \\
{ }^{\circ} \mathrm{C} \text { ). Mixture of carbonates, kaolin and talc; } 23 \% \\
\text { THF extract. Complex mixture of wood extractives } \\
\text { and their derivatives, polyacrylates and polystyrene } \\
\text { compounds. }\end{array}$ & $(60)$ \\
\hline $\begin{array}{l}\text { Deposits in the wet end } \\
\text { forming fabric and the } \\
\text { press section of a mill } \\
\text { producing corrugating } \\
\text { medium and testliner } \\
\text { boards from } 100 \% \\
\text { recovered paper }\end{array}$ & $\begin{array}{l}\text { Trichloromethane } \\
\text { extraction and FTIR } \\
\text { analysis }\end{array}$ & Main component detected: EVA & (61) \\
\hline
\end{tabular}


The location of the different deposits seems to play an important role in the composition of the deposits. PVAc is more susceptible to form deposits than other stickies-related compounds in the drying section, as was also suggested by the studies of T. Sarja et al. ${ }^{31}$ and Johansson et al. ${ }^{41}$. Three of the six deposits in which PVAc was identified were found in the drying section of the paper machine, two other deposits were collected in the press section and one other in the approach system to the paper machine. Styrene compounds are less susceptible to form deposits in the drying section and more susceptible in the wire section of the paper machine, as has been also observed by T. Sarja et al. ${ }^{31}$ and Johansson et al. ${ }^{41}$. Two of the deposits in which they were identified were collected in the deinking process, another in the wire section, another in the press section and another in the ink roller. In the case of polyacrylates, they have been identified in the drying section in three cases, in the press section in two cases and on the ink roller in the other case. We have observed that polyacrylates are more susceptible to form deposits in the drying section, as was determined by T. Sarja et al. ${ }^{31}$ but contrary to that observed by Johansson et al. ${ }^{41}$, in which polyacrylates were less susceptible than PVAc to form deposits in the drying section.

As an example of the results, three of the most significant types of deposits analyzed are presented. First, a deposit collected in the press section, over the felt, during a cleaning stop (no. 21), is presented. FTIR spectra of the sample and its corresponding extract and residue in ethanol is shown in Figure 3. FTIR spectra of the original deposit revealed the presence of the kaolin and calcium carbonate characteristic bands in the high frequency region of the spectrum, at 3690 and $3620 \mathrm{~cm}^{-1}$ in the case of kaolin and at $2510 \mathrm{~cm}^{-1}$ in the case of calcium carbonate. An important presence of esters of fatty acids and resin acids was also detected, in the original deposit but especially after the ethanol extraction, in the regions of $2800-3000 \mathrm{~cm}^{-1}$ and $2400-2800 \mathrm{~cm}^{-1}$. FTIR analysis of the residue obtained after ethanol extraction of the deposit showed once again kaolin and calcium carbonate characteristic bands. The morphology of the deposit (SEM) and the EDX analysis of the deposit are shown in Figure 4. The deposit consisted mainly of fibres of different sizes with sticky substances over the fibres, identified by FTIR as esters of fatty and resin acids. Small particles of calcium carbonate or kaolin in the fibers structure are also noticeable. EDX analysis of the deposit detected the presence of $\mathrm{Ca}, \mathrm{O}, \mathrm{Si}, \mathrm{Al}$, and traces of $\mathrm{S}$. This is in agreement with the FTIR analysis of the deposit which also demonstrated that the presence of calcium carbonate $(\mathrm{Ca}$ and $\mathrm{O})$ and kaolin was important $(\mathrm{Si}, \mathrm{Al}, \mathrm{O})$. It is concluded that this deposit consists mainly of esters of fatty acids/resins in the presence of fibers and inorganics (mainly kaolin and calcium carbonate). The origin can be found in the addition of deinking chemicals, based on fatty or resin acids, as the soap added in the flotation stage, or in the wood extractives associated to the recovered paper used as raw material in the paper mill.

Secondly, the analysis of deposit no. 2 is presented. This deposit was collected in the winder, during regular operations. It was detected as a black speck on the paper. Figure 5 
shows the FTIR spectra of the original deposit and the corresponding extracts in ethyl acetate and trichloromethane. In the high frequency region of the spectrum, weak bands appeared for kaolin $\left(3623\right.$ and $\left.3699 \mathrm{~cm}^{-1}\right)$ and calcium carbonate $\left(2510 \mathrm{~cm}^{-1}\right)$. After the extraction in ethyl acetate and trichloromethane, fatty acid salts were found in the 28003000 and $2400-2800 \mathrm{~cm}^{-1}$ regions. The presence of polyvinyl acetate was also identified because of the bands appeared mainly at 1740,1460 and $1250 \mathrm{~cm}^{-1}$. In any case, the main components of the deposits are polyacrylates (bands at about 1711, 1464 and $725 \mathrm{~cm}^{-1}$ ). FTIR spectra of the residues obtained in the ethyl acetate and trichloromethane extraction of the deposit showed bands corresponding mainly to the inorganic deposit components (kaolin and calcium carbonate) (Figure 6). The morphology of the deposit (SEM) and the EDX analysis of the deposit are shown in Figure 7. The deposit consisted of fibres of different sizes with sticky substances on the fibres, similar to that observed for deposit no. 21. Sticky substances were identified mainly as polyacrylates with a significant concentration of polyvinyl acetate and wood extractives. EDX analysis of the deposit detected the presence of $\mathrm{Ca}, \mathrm{O}, \mathrm{Si}, \mathrm{Al}$, and traces of $\mathrm{Fe}, \mathrm{S}$ and $\mathrm{K}$. This is in agreement with the FTIR analysis of the residue of ethyl acetate and trichloromethane extraction: the presence of calcium carbonate $(\mathrm{Ca}$ and $\mathrm{O})$ and kaolin was important $(\mathrm{Si}, \mathrm{Al}, \mathrm{O})$.

Thirdly, the analysis of a deposit consisting mainly of inorganics, deposit no. 6, is presented. This deposit was collected in the wire section during regular operation of the paper machine. Its appearance was hard greyish crumbs. As can be seen in Figure 8, the deposit is basically composed of cellulose and inorganic constituents such as calcium carbonate or kaolin. The presence of synthetic adhesives or wood extractives and their derivatives was not detected. SEM and EDX microanalyses of the deposit are shown in Figure 9. This deposit is homogeneous with small filaments on a smooth surface. EDX microanalysis of different locations of the deposits revealed the presence of $\mathrm{Ca}, \mathrm{S}, \mathrm{Si}$ and $\mathrm{Cl}$, probably with an origin in calcium carbonate, kaolin, talc, sulphates and silicates. The presence of low amounts of $\mathrm{Al}, \mathrm{Na}$ and $\mathrm{Mg}$, has also been observed.

Finally, the presence of the main compounds identified in the deposits, has been monitored along the deinking line of the process for determining its removal efficiency. Two different surveys have been carried out. It has been very difficult to determine concentration differences of the compounds between each stage of the deinking process but it has been possible to analyze the overall differences of the composition of the extracts from the first point of the line analyzed (inlet of the medium consistency slotted screen) and the final pulp. Figure 10 shows the FTIR spectra of the dichloromethane extractives obtained for the first and the last sample taken from the deinking line and Table 4 shows the main results obtained. 
Table 4.- Relative concentration of problematic stickies in the extract at the beginning and at the end of the deinking line.

\begin{tabular}{|c|c|c|c|c|}
\hline & \multicolumn{2}{|c|}{$1^{\text {st }}$ survey } & \multicolumn{2}{c|}{$2^{\text {nd }}$ survey } \\
\hline & Initial pulp & Final pulp & Initial pulp & Final pulp \\
\hline PVAc & +++ & + & +++ & +++ \\
\hline Polyacrylates & +++ & ++++ & +++ & ++ \\
\hline SBR & +++ & + & + & + \\
\hline EVA & + & + & + & + \\
\hline Waxes & ++ & ++ & +++ & +++ \\
\hline Fatty Acids & +++ & + & +++ & +++ \\
\hline PVA $_{\mathrm{OH}}$ & ++ & ++ & ++ & ++ \\
\hline
\end{tabular}

Legend: ++++ (predominant compound), +++ (high concentration), ++ (intermediate concentration), + (low concentration or traces).

Predominant components after the deinking operations vary slightly from one survey to another, but PVAc, polyacrylates, waxes and fatty acids seem to be the most predominant contaminants. No important differences have been observed in the relative concentration of the analyzed compounds in the dichloromethane extracts along the deinking line, indicating the tendency of these compounds for not being removed selectively, although the total stickies content has been reduced by nearly $80-90 \%{ }^{44}$. Indeed, in the second survey, there is almost no difference between the relative concentration of these substances in the extractives at the first and the last point of the deinking line, demonstrating the origin of these compounds in the first stages of the process (coming mainly from the recovered paper used as raw material) and their recalcitrance. As it was expected, the composition of the extractives is rather complex, these mixtures are usually formed by reagglomeration in, or shortly after, the pulper, from relatively pure stickies associated with the incoming furnish $^{47}$.

The presence of PVAc at the first point of the line is high in both surveys, but at the end of the line, there is a reduction of its presence in the extractives, especially in the first survey (see bands around $1250 \mathrm{~cm}^{-1}$ in Figure 10). Polyacrylates have also a high concentration at the beginning of the line; in the first survey, the relative concentration increases to be predominant compound in the dichloromethane extractives at the end of the line but in the second survey the contribution of polyacrylates to the extractives content decreases from high to medium (see bands at about 1711, 1464 and $725 \mathrm{~cm}^{-1}$ ). SBR is selectively removed to some extent by the deinking line in both surveys (see bands at about 1600 and $1450 \mathrm{~cm}^{-}$ $\left.{ }^{1}\right)$. However, the deinking line was not able to remove any waxes from the pulp in both surveys, relative importance of waxes to extractives content at the beginning of the line is similar to that at the end of the line, and the same occurs for PVA $\mathrm{OH}_{\mathrm{OH}}$ and EVA. Fatty acids were selectively removed in the first survey but no selective removal was observed in the 
second survey as can be seen in the $3000-2800 \mathrm{~cm}^{-1}$ region. Although FTIR is a semiquantitative technique, it seems very clear that the contaminants analyzed are hard to remove. Only a few studies have quantified the removal of some of the sticky-forming substances. According to J. Sjöstrom and B. Holmbom ${ }^{62}$ and F. Asp et al. ${ }^{63}$, PVAc and EVA are removed more efficiently (90-95\%) than SBR and polyacrylates (60-70\%). In our study, in the first survey, PVAc and SBR were removed similarly and more efficiently than polyacrylates for a similar concentration at the beginning of the line for the three components. In the second survey, no differences in the behaviour of these compounds were observed. Other studies such as H. Johannson et al. ${ }^{41}$ have analyzed the removal efficiency of both wood extractives and polymers (considered as the sum of PVAc, polyacrylates, polystyrene and polybutadiene) in a newsprint mill using $100 \%$ DIP. They found that the removal of wood extractives $(69 \%)$ was lower than the removal of polymers $(85 \%)$ but these differences are not enough to be corroborated in our study in which no important differences have been observed between the removals of PVAc, polyacrylates, or SBR and fatty acids.

The results obtained are partially in agreement with the study of D.K. Wilhelm et al. ${ }^{47}$. They found a mixture of PVAc and polyacrylate to predominate in the final accepts of two newsprint mills and their relative abundance increased as they move along the deinking process, although the total number of contaminants decreases substantially. The two mills studied had a different configuration and obtained their fiber from different sources, and although the similarity of their stickies profiles suggested that the recalcitrance of the PVAc/poly acrylate mixture may be universal and may apply to other newsprint mills, this is not completely true as demonstrated in this study.

One of the main differences between both surveys is the proportion of unusable material in the furnish. The fraction of furnish with a higher proportion of unusable material is the fraction coming directly from the selective collection in the "drop-off" containers and sorted at the paper mill. The proportion of unusable material in the fraction coming from the selective collection was around $6.5 \%$ on average during the previous month of the sampling of the $1^{\text {st }}$ survey while it was around $5.0 \%$ on average in the previous month of the sampling of the $2^{\text {nd }}$ survey. Average values of macrostickies in the final pulp, measured as reported previously by A. Blanco et al. ${ }^{27}$ (using a $150 \mu \mathrm{m}$ Somerville screen for isolation of macrostickies and image analysis for stickies measurement), were around $175 \mathrm{~mm}^{2} / \mathrm{kg}$ and $125 \mathrm{~mm}^{2} / \mathrm{kg}$ in the previous month of the samplings of the $1^{\text {st }}$ and the $2^{\text {nd }}$ survey, respectively. The identification of the main components involved in the formation of deposits in the unusable fraction of the furnish, shown in the next section, demonstrates that unusable material is an important source of stickies related components. 


\section{Recalcitrant stickies identification in the unusable material fraction of the furnish}

Results from the analyzed samples are summarized in Table 5. As an example, Figure 11 shows three of the fourteen analyzed samples and the exact position in which the sample was taken: a case material based on OCC (no.1), a board cereals box (no. 5) and a phone bill envelope with window (no. 10).

Table 5.- Main components detected in the samples of board fraction.

\begin{tabular}{|c|c|c|c|c|c|c|}
\hline No. & Description & PVAc & PAcry & EVA & SBR & $\begin{array}{l}\text { Other } \\
\text { components }\end{array}$ \\
\hline 1 & Carton board (corrugated) & Yes & Yes & Yes & Traces & Talc, $\mathrm{CaCO}_{3}(\downarrow)$ \\
\hline 2 & Box of dietetic biscuits & Yes & Yes $(\downarrow)$ & Yes & Yes $(\downarrow)$ & $\mathrm{CaCO}_{3}$ \\
\hline 3 & Printed folder (coated) & Yes & Yes & Yes & Yes & $\mathrm{CaCO}_{3}$ \\
\hline 4 & Carton board (corrugated) & No & Yes $(\downarrow)$ & No & Yes $(\downarrow)$ & $\mathrm{CaCO}_{3}$ \\
\hline 5 & Cereal box & Yes $(\downarrow)$ & No & Traces & No & $\mathrm{CaCO}_{3}$, talc $(\downarrow)$ \\
\hline 6 & Carton board (corrugated) & No & Yes $(\downarrow)$ & No & No & $\mathrm{CaCO}_{3}$ \\
\hline 7 & Cigarette box (body) & Yes & Yes & Yes & No & $\mathrm{CaCO}_{3}$, kaolin \\
\hline 8 & Cigarette box (tax sticky) & Yes $(\downarrow)$ & No & No & Traces & Talc \\
\hline 9 & Box of biscuits & Yes $(\downarrow)$ & No & No & No & $\mathrm{CaCO}_{3}$ \\
\hline 10 & Phone bill envelope & No & No & No & No & $\mathrm{CaCO}_{3}(\downarrow)$ \\
\hline 11 & Board box of a perfume & Yes & Yes & Yes & No & Talc \\
\hline 12 & Bathroom paper roll & No & Yes & No & No & Talc, $\mathrm{CaCO}_{3}(\downarrow)$ \\
\hline 13 & Box of a can of mussels & Yes & Yes $(\downarrow)$ & Yes & Yes $(\downarrow)$ & $\mathrm{CaCO}_{3}$ \\
\hline 14 & $\begin{array}{l}\text { Carton board (corrugated) } \\
\text { for ceramics }\end{array}$ & Yes & Yes & Yes $(\downarrow)$ & No & $\mathrm{CaCO}_{3}$ \\
\hline
\end{tabular}

It is clear that unusable materials contain adhesives detrimental to the process that can cause deposit formation in the manufacturing process. Samples contain many substances considered as recalcitrant stickies. Only in one of the 14 samples were none of the considered recalcitrant stickies detected. In the other 13 samples, PVAc, polyacrylates, EVA or SBR, were detected as the most predominant components, and, in some cases, the four components together in the same sample. PVAc and polyacrylates are present in approximately $3 / 4$ of the analyzed samples ( 10 of the 14 samples), in high concentration in 7 and 6 of the 14 samples, respectively. SBR and EVA are present to a minor extent, approximately to half of the samples ( 8 and 6 of the 14 samples, respectively), in high concentration in six samples in both cases. Therefore, polyacrylates and polyvinyl acetate are the most frequent potential stickies both in the MOW and also in the board fraction. These results are in accordance with the determination of recalcitrant stickies commonly found in the latest stages of the deinking process ${ }^{47}$. 
In the study of N.N.-C. Hsu et al. ${ }^{51}$, the potential stickies coming from the MOW fraction of the furnish were also analyzed by FTIR. They found that adhesives consisted mainly of polyacrylates and homo- or copolymers of vinyl acetate, especially noticeable was the presence of 2-ethyl-hexyl acrylate in some of the samples, the major monomer used to produce low- $T_{g}$ polymers for PSA. M. Muvundamina ${ }^{52}$ also found, analyzing mixed household recovered paper, that the major adhesives found in the furnish were acrylic and water-based products. The furnish was composed mainly of direct mail, magazines, directories and light weight paperboards.

The studied materials, considered as unusable material for recycled newsprint paper and, in general, graphic papers, are very detrimental to paper production. K. Patrick ${ }^{64}$ observed that the old corrugated containers (boards) coming with the old newsprints used as raw material can have 10 times more stickies than the old newsprints itself. A study by A. Roring et al. ${ }^{65}$ reported that reducing incoming percentage of board from $4.5 \%$ to $1.3 \%$ in the furnish reduced stickies by $56 \%$. P. Neukum et al. ${ }^{66}$ observed that the determined macro sticky content correlates with the proportion of packaging material in the recovered paper grades. The reduction in the amount of non-deinkable paper and board (packaging material) in the graphic paper for deinking results in a parallel brightness improvement of more than $2.5 \%$ points on average. In comparative pilot plant trails, it was found that about $1 \%$ packaging material in recovered paper for deinking leads to a brightness decrease after flotation of about $0.5 \%$. Depending on the quality level of the deinked pulp ( 65 or $60^{\circ}$ ISO brightness) to be reached, an amount of $2.5-3.5 \%$ of packaging material above the allowed level of $1.5 \%$ in the recovered paper to be deinked causes the paper mills additional costs between 22 and 32 euro/t DIP ${ }^{66}$. N-C. Hsu et al. ${ }^{51}$ also observed that stickies problems are even more severe in recycling MOW, especially when MOW contains assorted mixtures of file folders with adhesive labels, address labels, high quality printed matters, etc., in addition to white ledgers.

\section{CONCLUSIONS}

Analysis of deposits collected in various locations of a newsprint paper mill based on $100 \%$ recovered paper show that only a few compounds as the most problematic: PVAc, polyacrylates, styrene compounds, and fatty acids/resins esters. PVAc and acrylates seems to be more susceptible to form deposits in the drying section while styrene compounds do not have a clear tendency to form deposits at a particular location.

FTIR analysis of the dichloromethane extractives along the deinking line showed that PVAc, polyacrylates, waxes and fatty acids were the most predominant components present in the pulps from the first stages of the deinking line, confirming their origin in the 
recovered paper used as raw material and their recalcitrant nature because their low or negligible selective removal of these compounds along the stock preparation process.

Unusable material typically found together with the secondary fiber, mainly board and mixed office waste, contains the most detrimental components which are found in the deposits of stickies. The proportion of unusable material is critical for the deposition of stickies in the mill.

\section{ACKNOWLEDGEMENTS}

The authors want to express their acknowledgement to Holmen Paper Madrid, to the Community of Madrid for the financial support of PROLIPAPEL-CM (S-0505/AMB/0100) and to the European Union for the support of RODET (QLK5-2000-00749) and SHAKER (COOP-CT-032352). Donald MacNeil is also acknowledged for the review of the English of the manuscript.

\section{LITERATURE}

(1) European Declaration on Paper Recycling 2006-2010. European Recovered Paper Council. Brussels (Belgium), 2006.

(2) Blanco, A.; Negro, C.; Monte, C.; Fuente, E.; Tijero, J. The challenges of sustainable papermaking. Env. Sci. Tech. 2004, 38, 414.

(3) Faul, A. Quality aspects of recovered paper for deinking. Prog. Pap. Recycl. 2005, 15, 6.

(4) Fairbank, M.; Keenan, D.; Peters, H.; Prein, M.; Schwarzbach, A.; Wells, L. Effect of recovered paper quality and deinking process parameters on dirt levels in newsprint. Pulp Pap. Can. 2006, 107, 64.

(5) Emerson, D. Single stream vs. source separated recycling. BioCycle 2004, 45, 22.

(6) Sacia, W.K.; Simmons, J. The effects of changing ONP quality on a newsprint mill. Tappi J. 2006, 5, 13.

(7) Wagner, J.; Bülow, C. Quality management of recovered paper. Das Papier 2007, 1-2, 49.

(8) Park, S.-B.; Lee, J.-M.; Eom, T.-J. The control of sticky contaminant with enzymes in the recycling of wastepaper. J. Ind. Eng. Chem. 2004, 10, 72.

(9) Spiess, W.; Renner, K. Improving the efficiency of recovered paper screening or how to effectively control stickies. Wochenbl. Papierfabr. 2004, 132, 1002.

(10) Delagoutte, T. Management and control of stickies. Prog. Pap. Recycl. 2005, 15, 31.

(11) Douek, M.; Sitholé, B.; Banerjee, S. Survey of deposits and contaminants in mills using recycled fiber. Prog. Pap. Recycl. 2003, 13, 12. 
(12) Monte, M.C.; Blanco, A.; Negro, C.; Tijero, J. Development of a methodology to predict sticky deposits due to the destabilisation of dissolved and colloidal material in papermaking - application to different systems. Chem. Eng. J. 2004, 105, 21.

(13) Hubbe, M.A.; Rojas, O.J.; Venditti, R.A. Control of tacky deposits on paper machines: a review. Nord. Pulp Pap. Res. J. 2006, 21, 154.

(14) Guo, X.Y.; Douek, M. Analysis of deposits/stickies from newsprint mills using recycled fibre. J. Pulp Pap. Sci. 1996, 22, 431.

(15) Putz, H.J. In Papermaking Science and Technology, Vol. 4, Göttsching, L.; Pakarinen, H., Eds.; Fapet Oy: Jyväskylä, Finland, 2000; pp 441-498.

(16) Blanco, A.; Negro, C.; Monte, M.C.; Fuente, H.; Tijero, J. Overview of two major deposit problems in recycling: slime and stickies. Part II: Stickies problems in recycling. Prog. Pap. Recycl. 2002, 11, 26.

(17) Hamann, L.; Strauss, J. Stickies: definitions, causes and control options. Wochenbl. Papierfabr. 2003, 131, 652.

(18) Onusseit, H. The influence of adhesives on recycling. Res. Cons. Recycl. 2006, 46, 168.

(19) Doshi, M.R.; Dyer, J.M. Various approaches to stickies classification. Prog. Pap. Recycl. 2007, 16, 44.

(20) Severtson, S.J.; Wang, X.; Kroll, M.S. Development of environmentally benign pressure-sensitive adhesive systems via modification of substrate properties. Ind. Eng. Chem. Res. 2002, 41, 5668.

(21) Nowak, M.J.; Severtson, S.J.; Wang, X.-P.; Kroll, M.S. Properties controlling the impact of styrenic block copolymer based pressure-sensitive adhesives on paper recycling. Ind. Eng. Chem. Res. 2003, 42, 1681.

(22) Guo, J.; Severtson, S.J.; Kroll, M.S. Role of paper face stock properties in determining removal efficiencies of pressure sensitive adhesive films from recycling operations. Ind. Eng. Chem. Res. 2004, 43, 1443.

(23) Guo, J.; Severtson, S.J.; Gwin, L.E. Optimizing the monomer composition of acrylic water-based pressure sensitive adhesives to minimize their impact on recycling operations. Ind. Eng. Chem. Res. 2007, 46, 2753.

(24) Vähäsalo, L.J.; Holmbom, B. White pitch deposition and styrene-butadiene-rubber binder content in paper mill process water. Appita J. 2006, 59, 280.

(25) Laudone, G.M.; Matthews, G.M.; Gane, P.A.C. Observation of shrinkage during evaporative drying of water-based paper coatings. Ind. Eng. Chem. Res. 2004, 43, 712.

(26) MacNeil, D.; Holmbäck, A.; Lassus, A.; Hoel, H.; Roring, A.; Holmbom, B. Removal of fatty and resin acids in European deinking processes. Prog. Pap. Recycl. 2004, 14, 6.

(27) Blanco, A.; Miranda, R.; Negro, C.; Garcia-Suarez, C.; Garcia-Prol, M.; Sanchez, A. Full characterization of stickies in a newsprint mill: the need for a complementary approach. Tappi J. 2007, 6, 19.

(28) Holbery, J.D.; Wood, D.L.; Fisher, R.M. Analysis and characterization of contaminants in OCC recycle furnishes. Tappi J. 2000, 83, 57. 
(29) Blazey, M.A.; Grimsley, S.A.; Chen, G.C. Identifying active and passive components of machine deposits. 2005 TAPPI Practical Papermaking Conference, Milwaukee, WI, USA, May 2005; TAPPI Press: Atlanta, 2005, Session 1.

(30) Leclerc, D.F. Fourier Transform Infrared Spectroscopy in the Pulp and Paper Industry. In: R.A. Meyers (ed.). Encyclopedia of Analytical Chemistry: Applications, Theory and Instrumentation; John Wiley \& Sons, Ltd: New Jersey (United States), 2000, 8361:8388.

(31) Sarja, T.; MacNeil, D.; Messmer, M.; Reunanen, M.; Niinimaki, J. Analysis of stickies in deinked pulp. Part II: distribution of stickies in deinked pulp. Prof. Papermak. 2006, 1, 15 .

(32) Lee, H.L.; Kim, J.M. Quantification of macro and micro stickies and their control by flotation in OCC recycling process. Appita J. 2006, 59, 31.

(33) Sarja, T.; Zabihian, M.; Kourunen, P.; Niinimaki, J. New method for measuring potential secondary stickies in deinked pulp filtrates. Wat. Sci. Tech. 2004, 50, 207.

(34) Chai, X.-S.; Samp, J.C.; Yang, Q.F.; Song, H.N.; Zhang, D.C.; Zhu, J.Y. Determination of microstickies in recycled whitewater by headspace gas chromatography. J. Chromatogr. A 2006, 1108, 14.

(35) MacNeil, D.; Sarja, T.; Reunanen, M.; Xu, C.-L.; Holmbom, B. Analysis of stickies in deinked pulp. Part I: methods for extraction and analysis of stickies. Prof. Papermak. 2006, 1,10 .

(36) De Jong, R.L. Stickies classification. Prog. Pap. Recycl. 2004, 13, 43.

(37) Haynes, R.D. Measurement of micro stickies formation. Prog. Pap. Recycl. 2003, 12, 19.

(38) Doshi, M.R.; Blanco, A.; Negro, C.; Dorris, G.M.; Castro, C.C.; Hamann, A.; Haynes, R.D.; Houtman, C.; Scallon, K.; Putz, H.-J.; Johansson, H.; Venditti, R.A.; Copeland, K.; Chang, H.-M. Comparison of microstickies measurement methods. Part I: sample preparation and measurement methods. Prog. Pap. Recycl. 2003, 12, 35.

(39) Doshi, M.R. ; Blanco, A.; Negro, C.; Monte, C.; Dorris, G.M.; Castro, C.C.; Hamann, A.; Haynes, R.D.; Houtman, C.; Scallon, K.; Putz, H.-J.; Johansson, H.; Venditti, R.A.; Copeland, K.; Chang, H.-M. Comparison of microstickies measurement methods. Part II: results and discussion. Prog. Pap. Recycl. 2003, 13, 44.

(40) Sjöström, J.; Holmbom, B.; Wiklund, L. Chemical characteristics of paper machine deposits from impurities in deinked pulp. Nord. Pulp Pap. Res. J. 1987, 2, 123.

(41) Johansson, H.; Wikman, B.; Lindstrom, E.; Osterberg, F. Detection and evaluation of micro-stickies. Prog. Pap. Recycl. 2003, 12, 4.

(42) Venditti, R.A.; Chang, H.; Copeland, K.L. Evaluation of various adhesive contaminant (stickies) analysis methods: tracking stickies concentrations across unit operations in old corrugated container recycling plants. Prog. Pap. Recycl. 2005, 14, 9.

(43) Delagoutte, T.; Brun, J. Drying section deposits: origin, identification and influence of the recycling processes, deinking and packaging lines comparison. Rev. ATIP 2005, 59, 17. 
(44) Miranda, R.; Blanco, A.; Negro, C.; Tijero, J. Stickies removal in a deinking line of a newsprint mill: efficiency of the different process stages. Cellul. Chem. Technol. 2006, 40, 775 .

(45) Heise, O.U.; Kemper, M.; Wiese, H.; Krauthauf, E.A. Removal of residual stickies at Haindl Paper using new flotation technology. Tappi J. 2000, 83, 73.

(46) Delagoutte, T.; Brun, J.; Galland, G. Drying section deposits: identification of their origin. Inv. Tec. Pap. 2003, 40, 153.

(47) Wilhelm, D.K.; Makris, S.P.; Banerjee, S. Signature of recalcitrant stickies in recycled newsprint mills. Tappi J. 1999, 82, 63.

(48) Ackermann, C.; Putz, H.-J.; Göttsching, L. Potential of stickies in brown recycled fiber pulps. Prog. Pap. Recycl. 2002, 12, 32.

(49) Putz, H.-J.; Hamann, A.; Gruber, E. Examinations of sticky origin and sticky removal. Wochenbl. Papierfabr. 2003, 131, 883.

(50) Cao, B.; Heise, O. Analyzing contaminants in OCC: wax or not wax? Pulp Pap. Can. 2005, 106, 41.

(51) Hsu, N.N.-C.; Schroeck, J.J.; Errigo, L. Identification of the origins of stickies in deinked pulp. Tappi J. 1997, 80, 63.

(52) Muvundamina, M. Contaminant characterizaton from mixed household paper recycling. Tappi J. 1997, 80, 129.

(53) Pang, P.; Deslandes, Y.; Raymond, S.; Pleizier, G.; Englezos, P. Surface analysis of ground calcium carbonate filler treated with dissolution inhibitor. Ind. Eng. Chem. Res. 2001, 40, 2445.

(54) Guo, J.; Severtson, S.J. Inhibition of calcium carbonate nucleation with aminophosphates at high temperature, $\mathrm{pH}$ and ionic strength. Ind. Eng. Chem. Res. 2004, 43, 5411.

(55) Rudie, A.W.; Hart, P.W. Mineral scale management. Part II: fundamental chemistry. Tappi J. 2006, 5, 17.

(56) Douek, M.; Guo, X.-Y.; Ing, J. In 1997 TAPPI Recycling Symposium Proceedings, Chicago, IL, April 14-16, 1997; TAPPI Press: Atlanta, GA, 1997; pp. 313-330.

(57) Sarja, T. Measurement, nature and removal of stickies in deinked pulp. Ph.D. Dissertation, University of Oulu, Finland, June 2007.

(58) Wang, X.; Zhan, H.; Liu, Q.; Huang, H. Analysis of deposits/stickies on dry section of newsprint machine. China Pulp Pap. 2003, 22, 5.

(59) Holbery, J.D.; Fisher, R.M.; Wood, D.L.; Whiting, P.; Norman, M.; Stuart, J. In 1997 TAPPI Recycling Symposium Proceedings, Chicago, IL, April 14-16, 1997; TAPPI Press: Atlanta, GA, 1997; pp. 539-544

(60) Zule, J.; Dolenc, J. Physico-chemical characterization of detrimental paper machine deposits. Materiali in Tehnologije 2004, 38, 103.

(61) Crawford, D.S. Behaviour of wastepaper stickies in recycling mills. Appita J. 1992, 45, 257. 
(62) Sjostrom, J.; Holmbom, B. A scheme for chemical characterization of deposits in pulp and paper production. Pap. Рuи 1988, 70, 151.

(63) Asp, F. Detrimental substances in a deinking mill (in Swedish). M.S. Thesis, Abo Akademi University, Finland, 1994.

(64) Patrick, K. Stickies, still a critical concern for today's recycling plants. Paper Age 2006, 122, 28.

(65) Roring, A.; Soede, O.; Hegdal, A.; Rangul, B. In $12^{\text {th }}$ PTS-CTP Deinking Symposium Proceedings, Leipzig, Germany, April 25-27, 2006; Papertichnische Stiftung: Munich, Germany, 2006; paper 10.

(66) Neukum, P.; Renner, K.; Putz, H.-J. In $5^{\text {th }}$ CTP-PTS Advanced Training Course on Deinking Symposium, Grenoble, France, March 23-26, 2001; Centre Technique du Papier: Grenoble, France, 2001; paper 1. 


\section{LIST OF FIGURES}

Figure 1.- Scheme of the analysis of the deposits.

Figure 2.- Scheme of the paper machine.

Figure 3.- FTIR spectra of the deposit no. 21, and its ethanol extract and residue.

Figure 4.- SEM and EDX microanalysis of deposit no. 21.

Figure 5.- FTIR spectra of deposit no. 2, and their extracts in ethyl acetate and trichloromethane.

Figure 6.- FTIR spectra of the residue of the extraction with ethyl acetate and trichloromethane of deposit no. 2.

Figure 7.- SEM and EDX microanalysis of deposit no. 2.

Figure 8. - FTIR spectra of deposit no. 6, and their extract and residue in ethyl acetate.

Figure 9.- SEM (above) and EDX (below) microanalysis of deposit no. 6.

Figure 10.- Spectra of the extract from the first sampling point of the line analyzed and the final pulp: (a) first survey; (b) second survey.

Figure 11.- Examples of unusable materials used for the identification of the origin of recalcitrant stickies. 


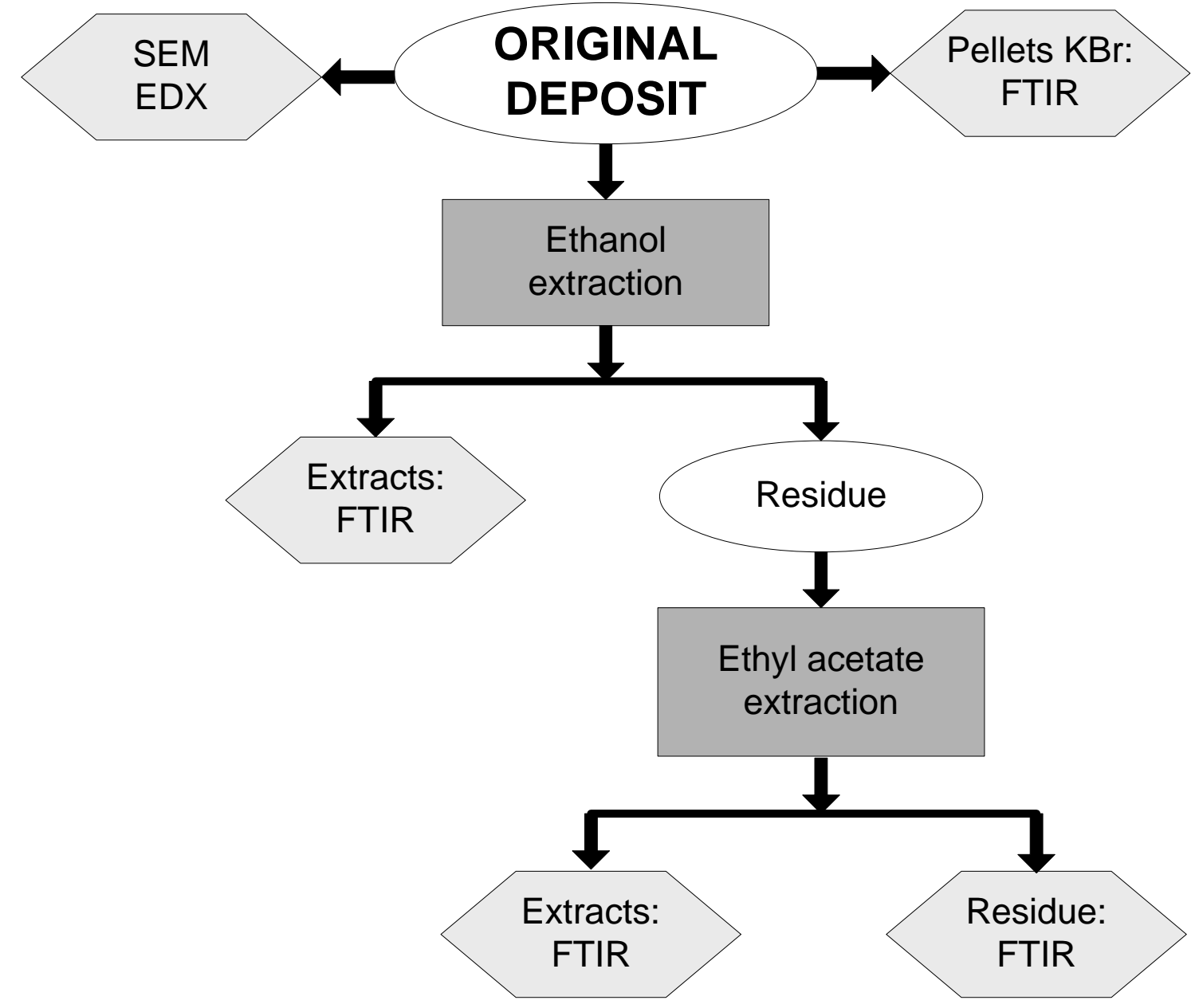

Figure 1.- Scheme of the analysis of the deposits. 

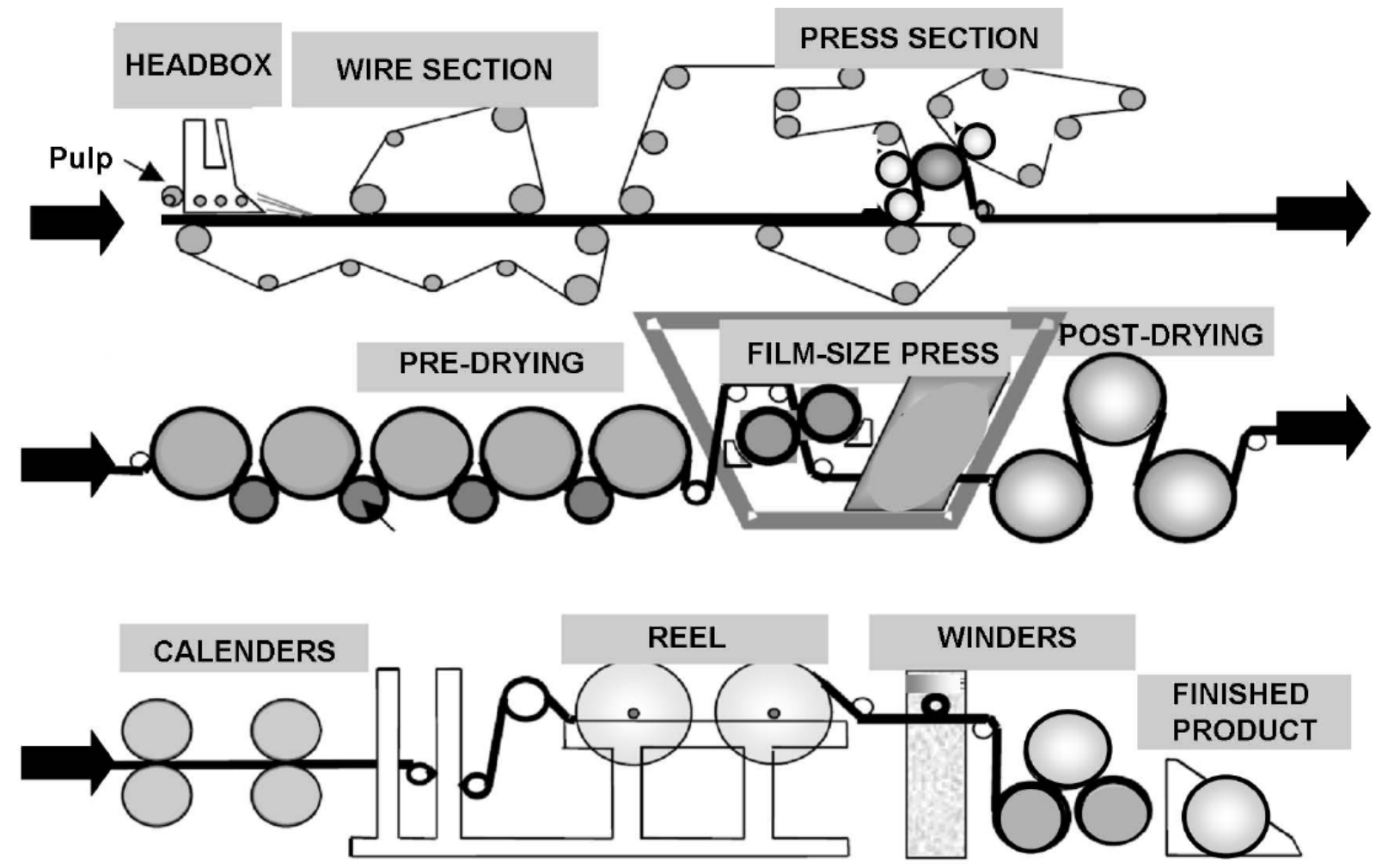

Figure 2.- Scheme of the paper machine. 


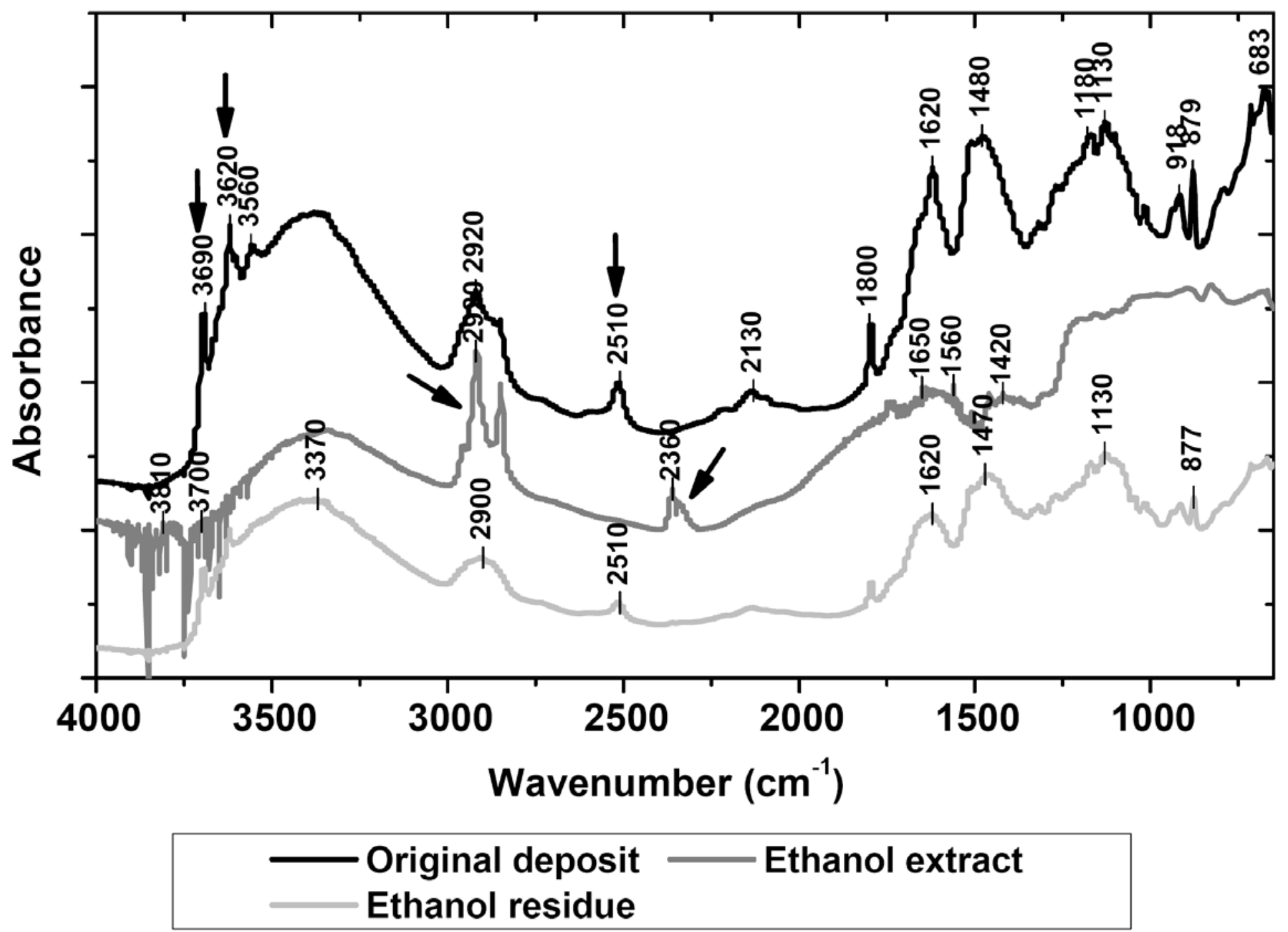

Figure 3.- FTIR spectra of the deposit no. 21, and its ethanol extract and residue. 

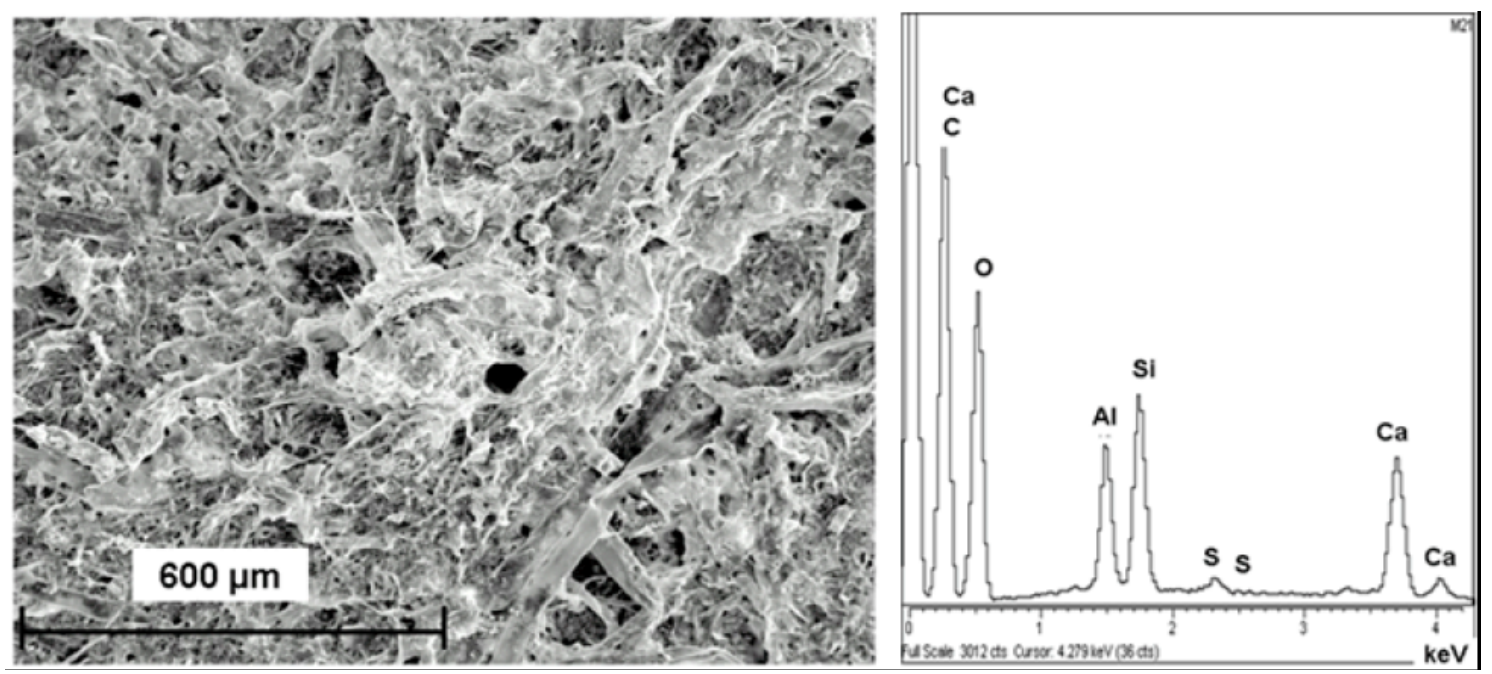

Figure 4.- SEM and EDX microanalysis of deposit no. 21. 


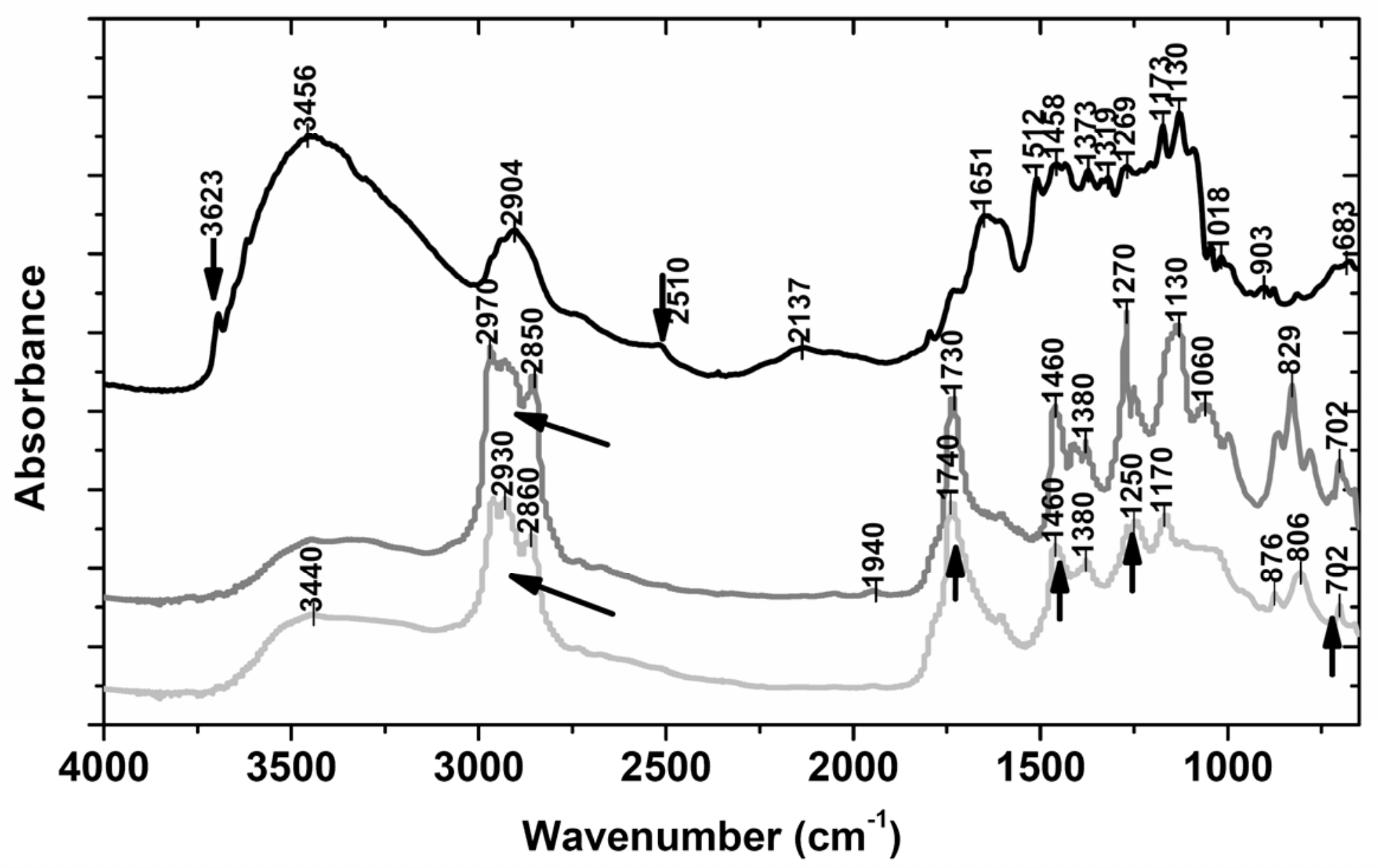

Original deposit ——Ethyl acetate extract Thrichloromethane extract

Figure 5.- FTIR spectra of deposit no. 2, and their extracts in ethyl acetate and thrichloromethane. 


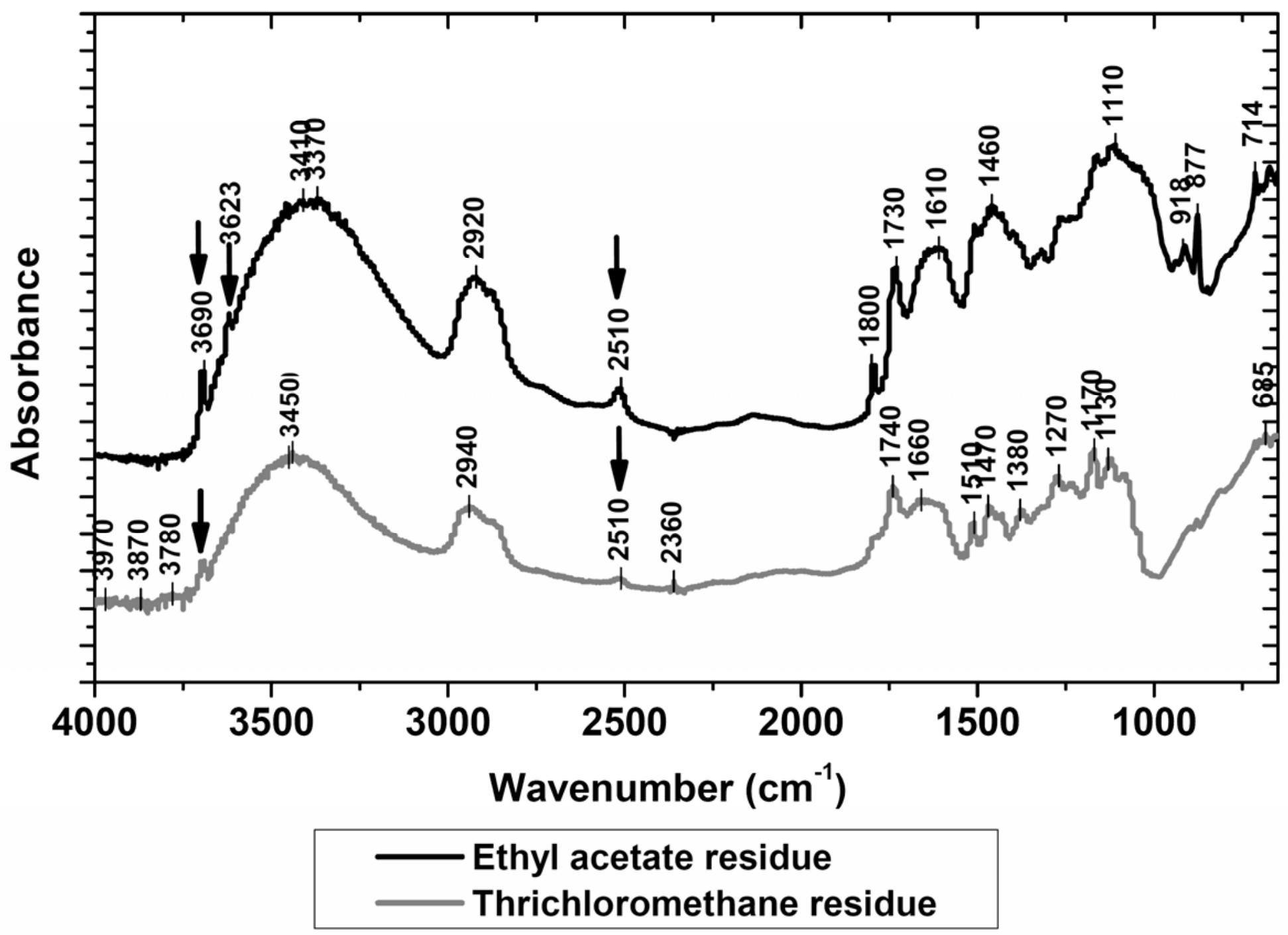

Figure 6.- FTIR spectra of the residue of the extraction with ethyl acetate and thrichloromethane of deposit no. 2. 


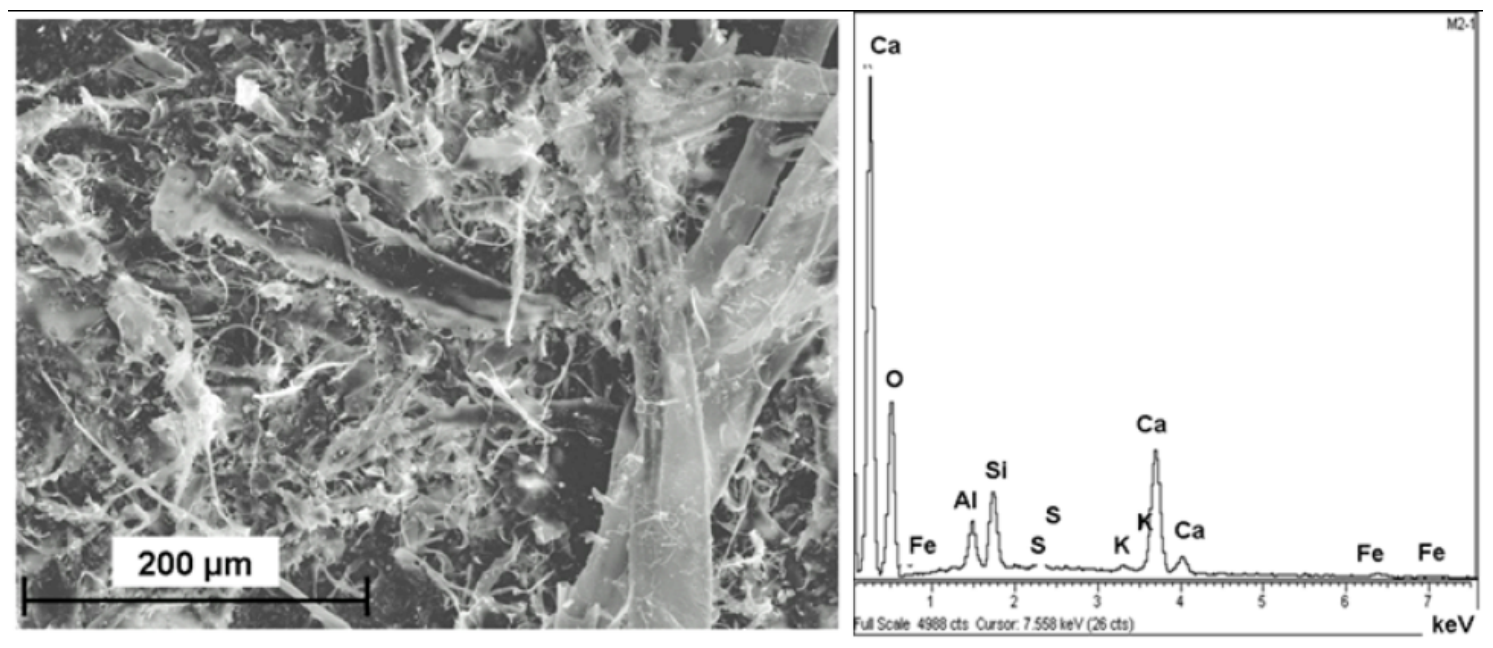

Figure 7.- SEM and EDX microanalysis of deposit no. 2. 


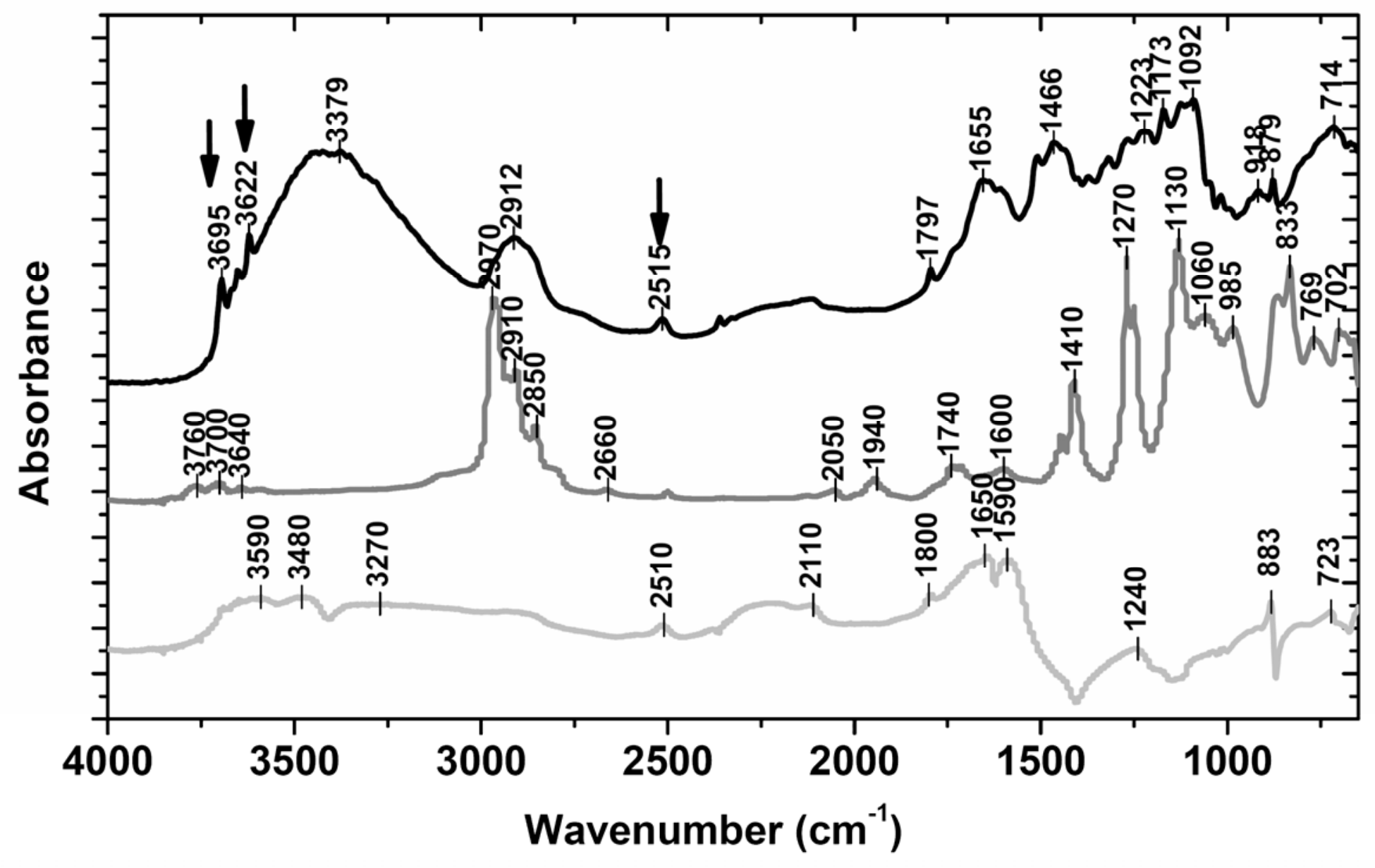

— Original deposit ——Ethyl acetate extract Ethyl acetate residue

Figure 8. - FTIR spectra of deposit no. 6, and their extract and residue in ethyl acetate. 

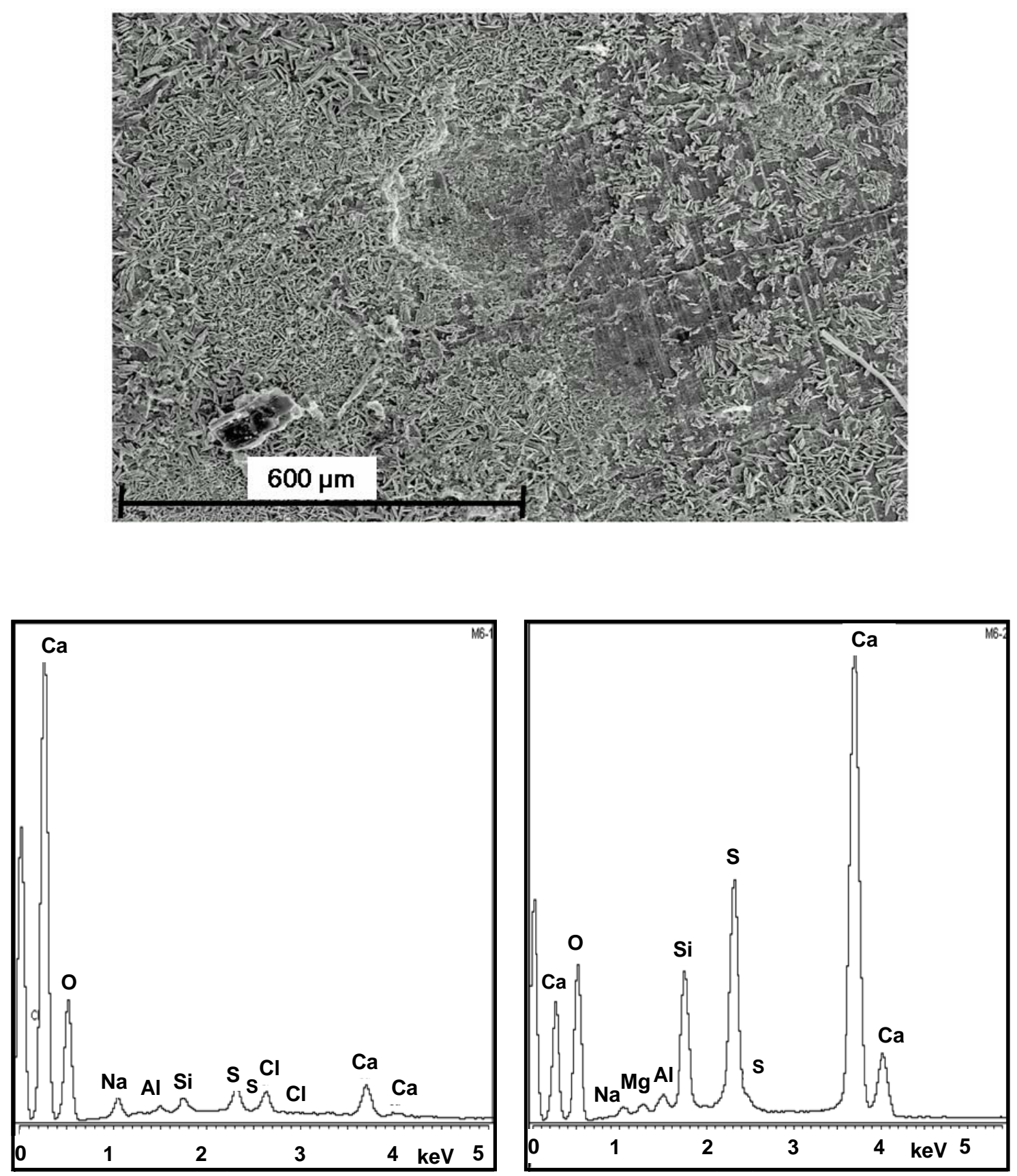

Figure 9.- SEM (above) and EDX (below) microanalysis of deposit no. 6. 

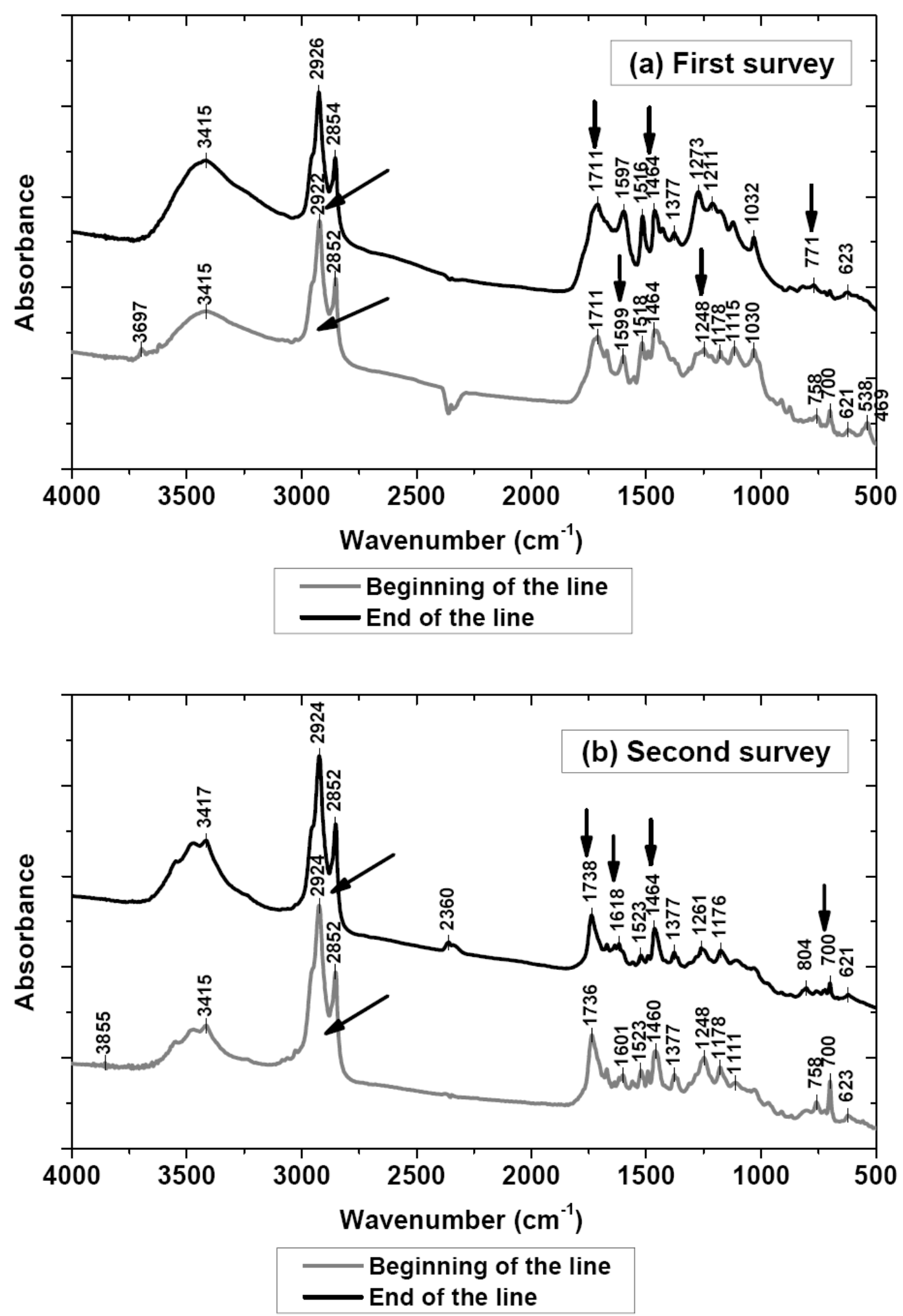

Figure 10.- Spectra of the extract from the first sampling point of the line analyzed and the final pulp: (a) first survey; (b) second survey. 

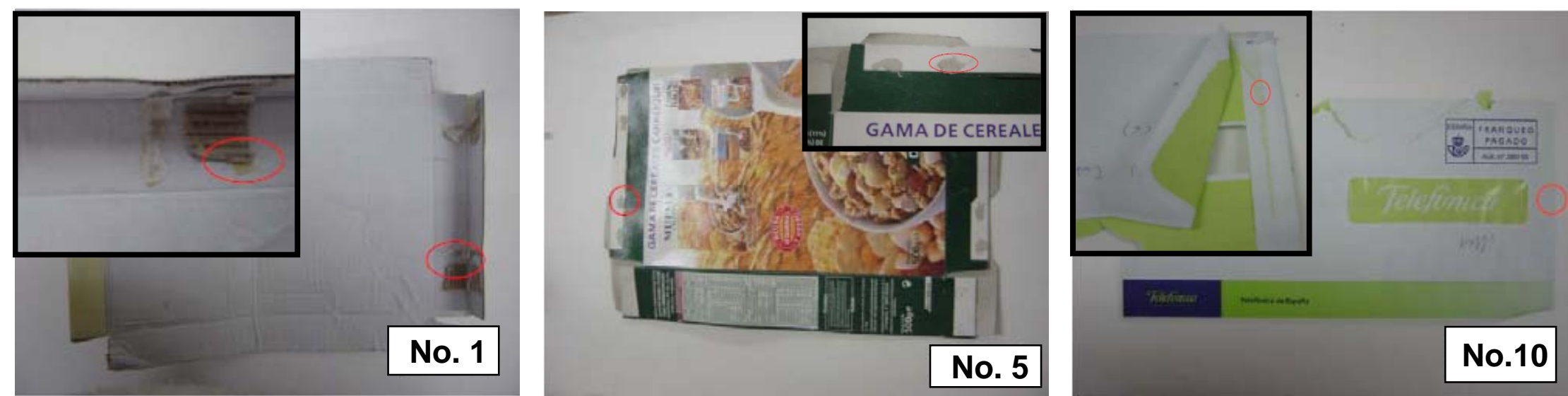

Figure 11.- Examples of unusable materials used for the identification of the origin of recalcitrant stickies. 